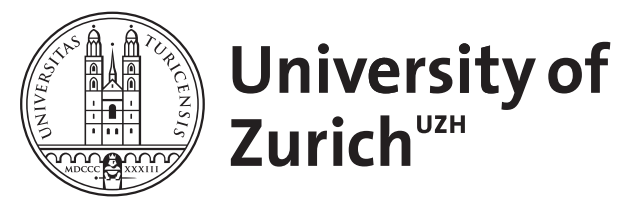

\title{
Four-gender systems in Indo-European
}

Loporcaro, M ; Paciaroni, T

\begin{abstract}
A long-established tenet of Indo-European linguistics says that grammatical gender systems all along the history of this language phylum were maximally tripartite and generally tended toward a reduction of gender contrasts. In this article, we shall show that this widely-held idea overlooks the existence of four-gender systems in a substantial part of the Romance language family, a fact that has in turn gone unnoticed so far. We shall provide an analysis of the relevant Romance data, a sketchy comparison with other four-gender systems described in linguistic typological research, and a detailed reconstruction of how the gender systems in question might have developed in the Latin-Romance transition.
\end{abstract}

DOI: https://doi.org/10.1515/flin.2011.015

Posted at the Zurich Open Repository and Archive, University of Zurich ZORA URL: https://doi.org/10.5167/uzh-55534

Journal Article

Published Version

Originally published at:

Loporcaro, M; Paciaroni, T (2011). Four-gender systems in Indo-European. Folia Linguistica, 45(2):389433.

DOI: https://doi.org/10.1515/flin.2011.015 


\title{
Four-gender systems in Indo-European ${ }^{1}$
}

\author{
Michele Loporcaro \& Tania Paciaroni \\ Universität Zürich
}

\begin{abstract}
A long-established tenet of Indo-European linguistics says that grammatical gender systems all along the history of this language phylum were maximally tripartite and generally tended toward a reduction of gender contrasts. In this article, we shall show that this widely-held idea overlooks the existence of four-gender systems in a substantial part of the Romance language family, a fact that has in turn gone unnoticed so far. We shall provide an analysis of the relevant Romance data, a sketchy comparison with other four-gender systems described in linguistic typological research, and a detailed reconstruction of how the gender systems in question might have developed in the Latin-Romance transition.
\end{abstract}

Keywords: grammatical gender (target vs. controller), language change, IndoEuropean/Romance historical linguistics, dialect variation

\section{Introduction}

In current studies on gender, in both the literature in linguistic typology and historical Indo-European linguistics, one invariably finds the claim that no Indo-European language has (or ever had) four grammatical genders. This is exemplified with the following quotation from Corbett's WALS article 'Number of genders':

\footnotetext{
${ }^{1}$ Thanks to Scott Collier and Alison Long for improving our English, as well as to Marcello Barbato, Walter Breu, Dunstan Brown, Marina Chumakina, Ashwini Deo, Ulli Dressler, Sebastian Fedden, Daniele Maggi, Carlotta Viti and one anonymous referee for comments and suggestions. Usual disclaimers apply. Although the article was conceived and developed jointly by the two authors, for academic purposes ML must be held responsible for sections $1,4,4.3,4.4$ and 5, TP for sections 3, 4.1 and 4.2; section 2 was co-written.
}

Folia Linguistica 45/2 (2011), 389-434.

ISSN 0165-4004, E-ISSN 1614-7308 @ Mouton de Gruyter - Societas Linguistica Europaea DOI 10.1515/FLIN.2011.015 
Given a gender system, the most common number of genders is two. [...] In Indo-European many languages retain three genders (like Icelandic and German), while many others have reduced to two (like French and Spanish); a minority has lost gender altogether (e.g. Eastern Armenian). Fourgender systems are particularly prevalent in Nakh-Daghestanian languages (our sample includes Archi, Lak and Tsez), though they occur elsewhere too, as in the isolate Burushaski. (Corbett 2005: 127)

The descriptive topos, as seen in this quotation, goes on contrasting the maximally ternary gender system of IE with four-gender systems occurring in other language families:

This system is not attested in Indo-European; it is found, however, in Burushaski (isolate), Dyirbal (Pama-Nyungan), as well as in some NE Caucasian languages. (Matasović 2004: 22 n. 6)

Burushaski, for instance (an isolate language spoken in the Karakoram region in Pakistan), displays the gender (agreement) system exemplified in (1) with the absolutive forms of the 3rd singular pronoun (also serving as a definite article), the demonstrative 'this', the question word 'which' as well as the two numerals 'one' and 'two' (cf. Lorimer 1935: 14-25; Berger 1998: 81-82, 100-102; Grune 1998: 3):

\begin{tabular}{|c|c|c|c|c|c|}
\hline$\underline{\text { Burushaski }}$ & 3SG (ABS) & 'this' & 'which?' & 'two' & 'one' \\
\hline $\begin{array}{l}\text { hm = MASCULINE } \\
\text { (male humans) }\end{array}$ & ne & khené & ámen & altán & hen \\
\hline $\begin{array}{l}\text { hf = FEMININE } \\
\text { (female humans) }\end{array}$ & mo & khomó & & & \\
\hline $\begin{array}{l}\mathrm{x}=\text { NEUTER }_{1} \text { (animals, } \\
\text { countable objects) }\end{array}$ & se & gusé & ámes & altác & han \\
\hline $\begin{array}{l}y=\text { NEUTER }_{2} \text { (mass } \\
\text { nouns, abstracts) }\end{array}$ & te & guté & ámet & altó & \\
\hline
\end{tabular}

The system is semantically based: the genders labelled by Burushaskianists $h m$ and $h f$ are assigned to male vs. female humans respectively, as in e.g. ne hir 'the.M.ABs man(M).ABs' vs. mo gus 'the.F.ABS woman(F).ABs'. As seen from the glosses, these two genders may as well be termed masculine vs. feminine, though keeping in mind that, in contrast to IE, they are strictly determined by the semantics and restricted to humans. The two further genders, called $x$ and $y$ by Burushaskianists, are assigned to 
non-humans (we shall term them here neuter ${ }_{1}$ vs. neuter ${ }_{2}$ ): the former is generally assigned to animals and countable objects, the latter generally to mass nouns and abstracts (although see section 4.3 for some exceptions), as exemplified by han/se hayór 'a.N/the. $\mathrm{N}_{1} \cdot \mathrm{ABS}$ horse $\left(\mathrm{N}_{1}\right)$.ABs' vs. te yéndes 'the. $\mathrm{N}_{2} \cdot \mathrm{ABS}$ gold $\left(\mathrm{N}_{2}\right) \cdot \mathrm{ABs}$ '.

In this article, we will show that there indeed exist some IE languages which do possess four distinct genders, and hence display a system that, despite the many differences, has some points in common with that of Burushaski. The article is organized as follows. In section 2, we shall succinctly review the literature on IE gender, in order to show that four-gender analyses are not usually proposed for any documented stage. In section 3 , we shall review the basic notions from research on gender in linguistic typology on which our analysis is going to elaborate. In section 4 we shall move on to analyze the Italo-Romance data from Central-Southern dialects which display a (previously unnoticed) four-gender system.

\section{Gender in Indo-European: state of the art}

Studies on IE gender agree in describing, for attested stages, and reconstructing, for the non-documented past of this language phylum, a maximum of three genders. The only exception we are aware of is Stang (1945), who claimed that in PIE a fourth gender should be added to the commonly assumed three, viz. the collective. As shown in (2), this claim was motivated with the observation that collective nouns ending in ${ }^{*}-\bar{a}\left(\right.$ or $^{*}-e h_{2}$, with the laryngeal notation in (4) below) selected an agreement pattern of their own, also realized by the complex morpheme $-e-h_{2}$ which was later captured into the inflectional system and gave rise to the neuter plural ending $-\bar{a} /-a$ of the attested IE languages (e.g. Old Greek phýll-a 'leaf(N)-NOM/ACC. PL.N', Latin castr-a 'fortress(N)-NOM/ACC.PL.N', Russian ókn-a 'window(N)NOM/ACC.PL.N' etc.):

(2) PIE gender according to Stang (1945: 282)

\begin{tabular}{|c|c|c|}
\hline & Adjective & Determiner \\
\hline Masculine & ${ }^{*}$ newos & ${ }^{*}$ so \\
\hline Feminine & ${ }^{*}$ newā & ${ }^{*} s \bar{a}$ \\
\hline Neuter & ${ }^{*}$ newom & ${ }^{*}$ tot/-d \\
\hline Collective & ${ }^{*}$ newā & ${ }^{*} t \bar{a}$ \\
\hline
\end{tabular}


The evidence leading Stang to this assumption was that, as first recognized by Schmidt (1889: 1-5), languages like Old Greek, Hittite (and, more generally, Anatolian), Avestan and Vedic show (remnants of) singular verb agreement with neuter plural nouns, as seen in the Greek example in $(3):^{2}$

(3) $t$-à phýll-a pípt-ei.

DEF-NOM.PL.N leaf(N)-NOM.PL.N fall.PRS-3sg

'The leaves fall'.

This agreement pattern is interpreted as a relic of the purportedly original state of affairs in (2). While the interpretation of data such as (3) as pointing to a stage in which the $\bar{a}$-ending nouns were not yet inflectional neuter plurals is uncontroversial, Stang's speculation that this is evidence for a fourth gender in the Proto-Language did not find wide acceptance. As Belardi (1950: 222) puts it, "le forme in $-\bar{a} / a$ non sono originariamente né collettivi singolari, né collettivi plurali, ma semplicemente dei collettivi" [the forms in $-\bar{a} / \partial$ are neither originally singular nor plural collectives, but simply collectives]. Collective is generally regarded as a separate number, rather than gender, a view which is implicit in Brugmann's (1886-1900, II 2: 431) statement according to which, for the process leading $\bar{a}$-forms to become (neuter) plurals, "man mag [...] von einem Numerussynkretismus sprechen" [one can speak of number syncretism]. ${ }^{3}$

Thus, once the collective is excluded, it is fair to say that for PIE a maximum of three genders (masculine vs. feminine vs. neuter) have been tra-

\footnotetext{
${ }^{2}$ Schmidt (1889: 1-5) was also the first to realize that this convergence warrants a reconstruction of this agreement rule for PIE, although observing that there are differences between those languages: e.g. this agreement pattern is systematic in Avestan, whereas it is only sporadically attested (with just three occurrences) in Vedic (cf. also Meier-Brügger 2002: 202-203).

${ }^{3}$ Eichner (1985) christened this fourth number, in addition to singular, plural and dual, "comprehensive" (see also Neu 1992: 197-212, Clackson 2007: 101). On this issue, there are a number of subtly different alternative views in the literature, including the one that the $\mathrm{PIE}^{*} e h_{2}$-collective originally was a derivational affix specified for number as either singular (Harðarson 1987: 83-84: "Der Übergang vom Kollektivum zum Plural impliziert den Übergang von einer derivationellen zu einer flexionellen Kategorie. [...] Das Kollektivum war im synchronen System des Uridg. als Singular eingeordnet." [The passage from collective to plural implies the passage from a derivational to an inflectional category. ... The collective was classed as singular in the synchronic system of PIE] - this view can be traced back to Schmidt 1889: 2, 5) or plural (Melchert 2011: 398: "inanimate pluralia tantum"). For others, ${ }^{*} \mathrm{eh}_{2}$-collectives were inflectional rather than derivational, and originally unspecified for number, as well as gender (cf. Litscher 2009, who elaborates on Friedman 1999, Balles 2004), at a stage in which the PIE number/gender system had not yet arisen.
} 
ditionally assumed. Nowadays, such a system ((4a)) is still assumed for a late stage of the Proto-Language (see Priestly 1983, Ostrowski 1985, Harðarson 1987, Euler 1991, Tichy 1993, Hajnal 1994, 2004, Melchert 1994, 2011, Stempel 1994, Fritz 1998, Zeilfelder 2001, Meier-Brügger 2002, Balles 2004, Matasović 2004, Litscher 2009, to mention just a few), although most of the cited studies on IE gender further reconstruct a two-gender system (common vs. neuter), ascribing to an earlier stage of PIE a pattern like the one attested in Hittite ((4b)) and Anatolian languages: ${ }^{4}$

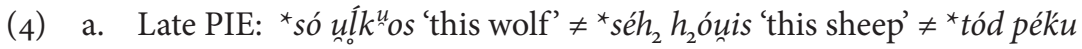
'this domesticated animal'

b. Hittite: $k \bar{a} s$ hartaggas 'this bear/predator' (common) $\neq k i ̄ h u i t a r$ 'this (wild) animal' (neuter)

Some scholars push the reconstruction even further, postulating a still more ancient genderless pre-PIE stage. Let us exemplify this stream of research by mentioning just one proposal. Ostrowski (1985) suggests that the two different inflectional classes to be reconstructed for PIE neuters, distinguished by (what later became) the NOM/ACC endings - $\varnothing$ (as in OInd ásthi 'bone', OGk êmar 'day') vs. -o-m (as in OInd dâna-m 'the giving', OGk ostéon 'bone'), originally must have formed one single paradigm, with the two forms occurring in complementary distribution according to the semantic feature [ \pm individuated] (Matasović 2004: 186 follows this view). Thus, for instance, ${ }^{*} m \bar{e} m s-\varnothing /{ }^{*} m \bar{e} m s o ́-m e d-m i$ must have been semantically distinct as, respectively, 'I eat meat [-individuated]' vs. 'I eat the/this meat', and this contrast must have been available, in principle, throughout the lexicon, at a stage in which nouns would not divide yet into distinct inflectional classes (of the kind familiar from Brugmann's reconstruction). This postulated syntactic mechanism for signalling individuation is compared by Ostrowski (1985: 319-320) with the one at work in south-western Vogul (or Mansi), a Uralic language of the Ugric branch. Here the unmarked form of a word like $k \bar{u} l-\varnothing$ 'fish' may occur in direct object position meaning '(non-individuated) fish' (as matter, or as a non-specific object), whereas in a sentence like 'I ate a (specific)/the fish', the accusative singular form $k \bar{u} l-m ə$ must be selected. From a similar starting point, it is maintained,

\footnotetext{
${ }^{4}$ Zeilfelder (2001: 153-239) recapitulates the discussion on whether the Anatolian two-gender system presupposes an earlier three-gender stage. Recently, Kim (2009) has proposed that Proto-Tocharian also split off from PIE with (still) a two-gender system, the masculine vs. feminine contrast being an independent innovation.
} 
the individual IE languages lost this (semantically motivated) syntactic rule and (what originally might have been) different forms within one and the same paradigm became distinct lexemes across languages (as in the pairs seen above) or even within the same language: e.g. OInd mās- vs. māmsá-, both meaning 'meat' (occurring in just three passages of the Rig-Veda, always with a specific reading; cf. Mayrhofer 1996, II: 343-344, 353, who glosses both as synonymous). This supposedly resulted in the rise of the two neuter inflectional classes, and of the common vs. neuter gender too, since (what later became) masculine nouns would show "die stärkste [...] innere Individuiertheit" [the stronger inner individuation] (Ostrowski 1985: 317) and therefore tend to occur with - $o-m$ inflection, which eventually became categorical, yielding the common (later masculine) accusative ending.

As a general remark, it can be observed that much of this literature on the rise of gender in (pre-)PIE almost exclusively focuses on noun inflection: a recent relevant example is Balles (2004), where gender agreement is not even mentioned. This is justified, to be sure, when dealing with overt gender, as is indeed the case for the neuter (NOM/ACC) endings ${ }^{*} \varnothing$ and ${ }^{*}-e_{2}(>-\bar{a})$ as well as for the common accusative ending ${ }^{*}-(o)-m$. (We are using the case/gender value-labels that define those endings in late, Brugmannian, PIE.) However, this de facto equation of gender (agreement) with inflectional class (see ( $7 a-b)$ for the definitions) entails the risk of terminological - and perhaps also conceptual - confusion, as witnessed e.g. by Clackson's (2007: 91) formulation: "Several languages have 'lost' one gender: in Romance, Modern Celtic and Modern Baltic, the neuter has been assimilated into the other two declensions". Strictly speaking, of course (see section 3), it is not the neuter (gender) per se but rather the lexemes formerly assigned to it that, as the neuter dissolved, migrated into declensions associated with one of the surviving genders. In this respect, Stang (1945), who explicitly addressed the issue of gender agreement on determiners (see (2)), in spite of his dubious results is more in keeping with the method of current typological research on gender than much of the later reconstructive work on PIE. ${ }^{5}$

Be that as it may, while the reconstruction of (the rise of) gender in the Proto-Language is a matter of lively debate, the later development of gen-

${ }^{5}$ See, however, Tichy (1993: 10-15), who locates the rise of feminine gender in the creation of dedicated pronominal forms ${ }^{\star} \mathrm{sah}_{2},{ }^{\star} \operatorname{tah}_{2} \mathrm{~m}$, first used for anaphoric resumption of female human referents. On the same line, see also Fritz (1998), Meier-Brügger (2002). 
der in the IE languages is uncontroversial, as general typological studies on IE gender agree on the picture in (5) (based on Priestly 1983, Matasović 2004, Igartua 2006):

(5) Modern developments of the Late-PIE three-gender system:

a. preserved: Greek, (most of) Slavic, (part of) Germanic (German, Icelandic, Faroese), (part of) Indo-Iranian;

b. reduction to two genders:

i. masculine $\neq$ feminine: Romance (except Romanian), part of Celtic (Irish, Scottish, Manx, Breton), Albanian, Baltic languages (except Old Prussian), some South Slavic dialects (Slovenian and Serbo-Croat), several Indo-Iranian languages (Hindi, Kashmiri, Rajasthani etc.);

ii. common $\neq$ neuter: part of Northern (East Scandinavian: Danish, Swedish) and Western Germanic (Dutch, Frisian);

c. loss of gender contrasts: Armenian, some Iranian languages (e.g. Modern Iranian, Sarykol, Baluchi, Ossetic), many Indo-Aryan languages (e.g. Nepali, Assamese, Bengali, Oriya), part of Germanic (English, Afrikaans).

It should be mentioned, however, that some analyses of individual languages did come up with larger (main) gender systems, as shown in n. 22 for Albanian. For Slavic languages, several analyses assume an increase in the number of genders. Thus, under Zaliznjak's (1964) account, Russian has six genders, resulting from combination of the three traditional values (masculine, feminine and neuter) with the [ \pm animate] contrast. Under different approaches, however, a system such as the Russian one still has three (main) genders, whereas the [ \pm animate] distinction is analyzed in terms of subgenders (cf. Corbett 1988, Comrie \& Corbett 1993: 16). Still, within a framework which assumes a gender vs. (animacy-based) subgender distinction, Brown (1998) comes up with an analysis of Polish which recognizes, in addition, a distinct main gender [masculine personal], yielding a total of four. In-depth discussion of the gender/subgender issue would by far exceed the scope of the present article. For our purposes, it is essential to observe that the picture in (5) is the one commonly agreed on in (largescale) comparative surveys of IE gender.

While preservation of the late PIE three-gender system is observed in a minority of languages $((5 \mathrm{a}))$, there has been a general drift toward its reduction. Furthermore, with the exception of the West and North Germanic 
developments in (5b-ii), ${ }^{6}$ this reduction usually involved the loss of the neuter. Occasionally, the neuter has been reshaped semantically, although remaining a third distinct gender: within Indo-Aryan, this was the case in Konkani (cf. Miranda 1975: 209-213). Here, in the Mangalore Christian dialects and in both the Christian and Hindu Konkani dialects of Goa, the inherited neuter was reanalyzed as a gender which may be defined as 'younger-feminine', as shown in the glosses in (6), where the diachronic development of the gender-agreement morphemes from PIE to Konkani is also displayed: ${ }^{7}$

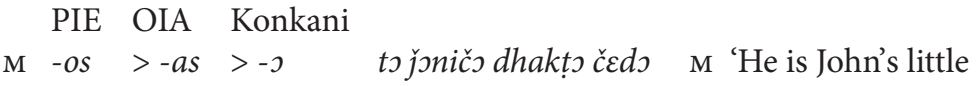

$$
\begin{aligned}
& \text { boy' } \\
& \mathrm{F}-\bar{a}>-\bar{a}>-i \quad \text { ti jonniči dhakți bhoyn } \mathrm{F}_{1} \text { 'She is John's little } \\
& \text { sister' }
\end{aligned}
$$

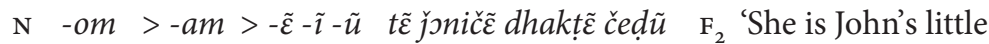

$$
\begin{aligned}
& \text { girl' }
\end{aligned}
$$

In closely related Marathi, where this change has not taken place, the original masculine vs. feminine vs. neuter contrast still occurs: cedā 'boy/ $\operatorname{son}(\mathrm{M})^{\prime} \neq$ ced 'little girl(F)' $\neq$ cedu 'little child(N)' (cf. Turner 1966: 267, Miranda 1975: 209 n. 14). However, as far as the overall architecture of the Konkani gender system is concerned, one can conclude that the change in (6) affected the semantics of the third gender, while leaving the system itself untouched, since this remained tripartite. On the contrary, the changes we are going to review, which took place in a substantial part of

\footnotetext{
${ }^{6}$ To quote just one Germanic example, Ebert (1998) shows that Fering, the variety of Frisian spoken on the island of Föhr, still preserves a three-way gender distinction contrary to what is usually reported on the Frisian gender system having shrunk homogeneously to a binary contrast of the (5bii) type. In Fering, the definite article selected with masculine vs. neuter nouns is categorically $a$ vs. at (e.g. a dochter 'the.M doctor(M)' vs. at hüs 'the.N house(N)'), whereas before feminine nouns both forms can occur: alat wüf 'the.F woman(F)'). Thus, although many formerly feminine nouns have become neuter or masculine, so that the feminine gender is in the process of being depleted, this process did not reach completion and nouns like wüf still belong to a third (controller) gender (see Corbett 1991: 151, discussed below in section 3). Moreover, nineteenth-century descriptions - Ebert shows - still report a three-way (target gender) contrast for the anaphoric article: di maan 'the.m $\operatorname{man}(\mathrm{M})^{\prime}$ 'vs. $\operatorname{det}$ hüs 'the.N house(N)') vs. jü wüf 'the.F woman(F)'), with a distinct form $j \ddot{u}$ for the feminine, nowadays replaced by det (and henceforth merged with the neuter).

7 The table in (6) reproduces the diachronic derivation provided by Miranda (1975: 209). In the feminine, the Old Indian $-\bar{a}$ and $-\bar{\imath}$ endings merged via a morphophonemic change (see Bloch 1934: 136).
} 
Italo-Romance dialects, did affect the architecture of the gender system itself, yielding a result which does not match any of the options listed in $(5 a-c)$.

\section{Analyzing gender}

In order to develop our analysis of the Italo-Romance data, we have to introduce a few analytical tools, starting from the gender vs. inflectional class distinction, as defined in $(7 \mathrm{a}-\mathrm{b})$ :

(7) a. Genders are classes of nouns reflected in the behavior of associated words. (Hockett 1958: 231, cited by Corbett 1991: 1)

b. An inflectional class is a set of lexemes whose members each select the same set of inflectional realizations. (Aronoff 1994: 182)

The distinction is illustrated in (8) with the example of a 'well-behaved' modern Romance language of type (5b-i), viz. Logudorese Sardinian: ${ }^{8}$

\begin{tabular}{|c|c|c|c|c|c|}
\hline \multirow{2}{*}{$\begin{array}{l}s-u \\
s-u\end{array}$} & yadd-u & \multirow{2}{*}{$\begin{array}{l}\text { mann-u } \\
\text { mann-u }\end{array}$} & Class 2, pl. -os & \multirow{2}{*}{$\mathrm{M}$} & DEF-M.SG horse(M)-SG big-M.SG \\
\hline & 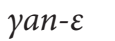 & & \multirow{2}{*}{ Class 3, pl. $-\varepsilon s$} & & DEF-M.SG $\operatorname{dog}(\mathrm{M})$-SG big-M.SG \\
\hline \multirow{2}{*}{$\begin{array}{l}s-a \\
s-a\end{array}$} & $r u \gamma-\varepsilon$ & mann-a & & \multirow{2}{*}{$\mathrm{F}$} & DEF-F.SG $\operatorname{cross}(\mathrm{M})$-SG big-F.SG \\
\hline & $\gamma r a \beta-a$ & mann-a & Class 1, pl. -as & & DEF-F.SG goat(M)-SG big-F.SG \\
\hline$\overline{4}$ & \multicolumn{3}{|c|}{ Noun endings: three infl. classes } & 4 & \\
\hline
\end{tabular}

As highlighted by the boxes, there is a bidirectional mismatch, as nouns from different inflectional classes may belong in the same gender (e.g. $s u$ yadd $u$ < CABALLUM and $s u$ yane < CANEM are both masculine) and, conversely, nouns of the same inflectional class may belong in different genders (thus, su yane is masculine while sa ruye 'the cross' is feminine, as were, respectively, their Latin ancestors CANEM vs. CRUCEM). ${ }^{9}$

\footnotetext{
${ }^{8}$ The four NPs listed in (8) translate as 'the big horse/dog/cross/goat'. Here and in the following, Italo-Romance dialect data are given in a simplified IPA transcription: (allophonic) vowel length is omitted, consonant gemination is notated CC and stress is marked only on non-paroxytonic words, except in dialects presenting reduction to $a$ of unstressed posttonic vowels. In that case, the last non-reduced vowel carries stress. Whenever unreferenced, the dialect data stem from our own fieldnotes.

${ }^{9}$ Following traditional usage in Romance linguistics, Latin etyma are given in small caps and in the accusative form, which became generalized in the Romance languages. By con-
} 
A further analytical tool which is going to prove useful for our analysis is the distinction between target vs. controller gender (Corbett's 1991: 151 terminology) or inflectional vs. selective gender (in Hockett's 1958: 230 terms):

We should therefore differentiate controller genders, the genders into which the nouns are divided, from target genders, the genders which are marked on adjectives, verbs and so on (Corbett 1991: 151).

Corbett illustrates the notion controller gender with a Romance language, viz. Romanian, for which three genders are commonly assumed (see e.g. Graur 1928, Bonfante 1964, 1977, Jakobson 1971: 187-189, Schmidt 1972: 35-39, Aikhenvald 2000: 45-46, Matasović 2004: 51-52, Igartua 2006: 60-61, Acquaviva 2008: 135-140), although the sets of distinct agreeing forms available to mark gender on adjectives, pronouns etc. are just two. ${ }^{10}$ This is schematized with adjective inflections in (9), and illustrated in (10) with one example for each gender.

(9) The gender system of Romanian (Corbett 1991: 151)

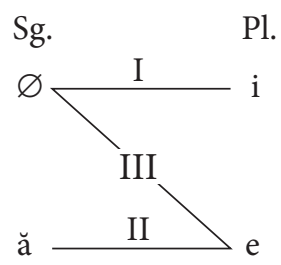

trast, Latin forms are given in italics whenever they are mentioned per se, rather than as diachronic sources of their Romance descendants.

${ }^{10}$ Some have maintained a two-gender analysis for Romanian, e.g. Hall (1965) or, more recently, Bateman \& Polinsky (2010), Maiden (2011: 701, n. 36). However, the reasoning leading to this conclusion suffers from conceptual errors, starting with the definition of (gender) agreement as "covariation between the form of the trigger (noun) and the form of the target (such as adjectives and articles)." (Bateman \& Polinsky 2010: 41) [emphasis added]. The problem lies in the reference to the controller's form - lacking, and with good reason, from the definition in $(7 \mathrm{a})$ - which obliterates the key distinction between overt and covert gender and thus renders impossible an account of, say, Latin bonus incola 'good inhabitant' and bonus homo 'good man' (as opposed to bona puella 'good girl', inflecting like incola) as belonging to one and the same gender. 
(10) Singular
a. M student-ul
e bun
student(M)[sG]-DEF.M.SG be.3SG good[M.sG]
b. $\mathbf{N}$ vin-ul
e bun
wine (N)[sG]-DEF.M.SG
be.3SG good[M.SG]
c. F băutur-a
e bun-ă
$\operatorname{drink}(\mathrm{F})$ [SG]-DEF. M.SG be.3SG good-F.SG
'The student/wine/drink is good.'

\section{Plural}
a. M studenți-i
sunt bun-i
student(M).PL-DEF.M.PL
be.3PL good-M.PL
b. $\mathrm{N}$ vinuri-le
sunt bun-e
wine(N).PL-DEF.F.PL
be.3PL good-F.PL
c. F băuturi-le
sunt bun-e
$\operatorname{drink}(\mathrm{F})$.PL-DEF.F.PL
be.3PL good-F.PL
'The students/wines/drinks are good.'

The neuter used to be not only a controller but also a target gender in Latin (i.e. it had dedicated agreement forms: e.g. bon-um 'good-NOM.sG.N'vs. bon-us 'good-NOM.SG.M' vs. bon-a 'good-NOM.SG.F') but became a controller gender in Romanian, as the gender agreement markers merged with those for the masculine in the singular, and with those for the feminine in the plural, yielding the picture in (9). The alternating agreement pattern resulting from the change shows that neuter nouns like vin 'wine' in (10b), whose paradigm in the indefinite consists of two forms (singular and plural), qua lexemes behave differently from both masculine and feminine nouns. This satisfies the definition of gender in ( $7 \mathrm{a}$ ): thus, the Romanian neuter is a gender, if only a controller gender. This is currently recognized also in studies on gender by specialists of IE: cf. Priestly (1983: 348), Matasović (2004: 51-52), Igartua (2006: 60-61).

The reason why (1ob) is acknowledged as a separate gender is that the nouns selecting that agreement pattern "form a large and coherent class" (Matasović 2004: 52). Indeed, neuter agreement is required by several distinct inflectional classes, some of which have been productive all along the history of Romanian. This applies to the one exemplified in (10b) by vin, vinuri 'wine,-s', whose plural inflection goes back to Latin -OR(A), reanalyzed as an ending within third declension $s$-stem neuters 
like TEMPUS, TEMPOR-A (> ${ }^{*}$ TEMP-ORA) 'time,-s' (> timp, timpuri). ${ }^{11}$ Since this inflectional class enjoyed large productivity also in Italo-Romance (cf. n. 19), its rise must be set at quite an early date in the development of (Central-Eastern) Late Latin: the earliest examples of plurals like armora 'weapons' (instead of classical arma), witnessing to the reanalysis of -ora as a plural marker, date back to the fourth century (cf. Aebischer 1933: 71).

The other main productive inflectional class associated with neuter gender is bilet, bilete 'ticket,-s', ${ }^{12}$ whose plural ending was modified by analogy on feminine capră, $-e$ 'goat, $-s$ ', with $-e$ replacing the original neuter plural ending $-\breve{a}<-\mathrm{A}$. This regular outcome is still to be found only in ou, ouă 'egg,-s' < ovUM, -A, due to phonological reasons (stem-final $w$-glide). For the remaining neuter nouns, combination of the reshaping of the plural ending (with - $\breve{a}$ ousted by $-e$ or $-(u r) i)$ with base allomorphy and/ or morphophonological rules resulted in a series of several other inflectional (micro)classes, all selecting the agreement pattern (10b): cap, capete 'head,-s', teatru, teatre 'theater,-s', pârîu, pâraie 'stream, -s', chipiu, chipie 'kepi,-s', bordei, bordeie 'hut,-s', bici, bice 'whip,-s', nume, nume 'name,-s', consiliu, consilii 'advice, -s', râu, râuri 'river,-s' (cf. Bejan 2001': 37-38).

The same three-gender analysis just illustrated for Romanian, with the inherited neuter having reduced to a genus alternans (controller gender), is proposed in IE linguistics for Tocharian too:

genus alternans [...] was coined to cover the specific nature of the third gender in Tocharian, which combines agreement traits of the other two, the masculine and the feminine. This third noun class is traceable to the IE. neuter gender, but in Tocharian A and B nouns pertaining to this inflectional class take masculine agreement in the singular and feminine in the plural. (Igartua 2006: 58)

\footnotetext{
${ }^{11}$ Until the eighteenth century, this plural ending was -ure (e.g. piept, piepture 'breast,-s'; Spitzer 1941: 339), modified by analogy on the feminine ending $-e<-\mathrm{AE}$, while today's -uri was reshaped on the analogy of the plural ending $-i<-\overline{\mathrm{I}}$, occurring notably in masculine nouns (e.g. pom, pomi 'tree,-s'). The productivity of this class is witnessed by the adaptation of loanwords such as dulap, dulapuri 'cupboard,-s' (< Turkish dolab), chimono, chimonouri 'kimono,-s' (< Japanese kimono).

${ }^{12}$ This class is today the most productive one among those associated with the neuter. In fact, the anonymous referee observes here that -uri plurals are receding somewhat in contemporary Romanian to the advantage of $-e$, so that e.g. chibrite 'matches' is now more common than traditional chibrituri. The same trend is reflected in the widespread use of $-e$, rather than uri, in more recent loanwords: e.g. walkman, walkmane, not ${ }^{*}$ walkmanuri.
} 
The agreement paradigm that motivates this analysis is exemplified in (11) with the demonstrative (after Krause \& Thomas 1960: 75-76, Schmidt 1972: $15-32)$ :

\begin{tabular}{|c|c|c|c|c|c|c|}
\hline \multicolumn{4}{|c|}{ Singular } & \multicolumn{3}{|c|}{ Plural } \\
\hline & Tocharian A & $\underline{\text { Toc }}$ & harian B & Toch & $\operatorname{arian} \mathrm{A}$ & Tocharian B \\
\hline M. & säs käșși & se & käșsi & ceș & käșșin & cai käșșint \\
\hline & säs oko & se & oko & toș & okontu & toy okonta \\
\hline & sās $y t a \bar{r}$ & $s \bar{a}$ & $y t a \bar{r}$ & toș & ytāräm & toy ytariñ \\
\hline
\end{tabular}

Unlike demonstratives modifying a noun head (as in (11)), the demonstrative pronoun has preserved three distinct forms (B $s e$ 'this.M' vs. $s \bar{a}$ 'this.F' vs. te 'this.N'), though only in the singular. According to Kim (2009: 84), on the other hand, who claims that Proto-Tocharian had two genders like Anatolian (see n. 4), it was the demonstrative pronoun, displaying a distinct feminine form ${ }^{*} \mathrm{seh}_{2}$, that aided the rise of a separate feminine (controller) gender within the nominal system.

Summing up, we have seen on the one hand that in the literature in IE linguistics it is usually maintained that IE languages have (and always had) a maximally ternary gender system. Furthermore, we have seen that the idea that a controller gender (genus alternans) is a gender in its own right is widely accepted in this line of research, and that analyses of this kind are currently proposed. This will have to be kept in mind in order to place into the appropriate context the Italo-Romance dialect data to be analyzed in what follows.

\section{The alternating gender in Italo-Romance}

Italian shows the same agreement pattern as displayed by the Romanian neuter in (9) and (10). Contrary to Romanian, however, this pattern occurs in Italian with just a small, nowadays unproductive, class of controller nouns, exemplified in (12) (subdivided into (12a) names of body parts, (12b) other names denoting entities naturally occurring in series, and (12c) count nouns denoting units of measure/quantity): 
(12) a. il braccio/le braccia 'the arm/-s', il dito/le dita 'the finger/-s', il ginocchio/le ginocchia 'the knee/-s', il ciglio/le ciglia 'the lash/-es', il sopracciglio/le sopracciglia 'the eyebrow/-s'

b. il lenzuolo/le lenzuola 'the sheet/-s', il muro/le mura 'the wall/-s', l'uovo/le uova 'the egg/-s', il grido/le grida 'the cry/cries', l'urlo/le urla 'the scream/-s'

c. il miglio/le miglia 'the mile/-s', il paio/le paia 'the pair/-s', un centinaio/tre centinaia 'one/three hundred', un migliaio/tre migliaia 'one/ three thousand'

This inflectional class derives historically from Latin 2 nd declension neuters: compare uovo,- $a$ < ovUM, -A with Romanian ou, ouă 'egg,-s' (section 3). This class first expanded throughout the history of Latin: for instance the plural ioca 'games', which in Romance yielded to giochi < IOcİ, is first attested in Lucretius (first century BC), whereas digita (whence Italian dita 'fingers') is first attested as late as the sixth century AD (cf. Eichner 1985: 145-146), much later than the classical (masculine) form digiti. In Old Italian too, the inflectional class in (12) enjoyed moderate productivity (see Gardani 2009: 519), to then gradually shrink over time along the history of Modern Italian. ${ }^{13}$

The analysis of the Italian data in (12) is highly controversial. Structurally, the picture is similar to Romanian (or Tocharian), as seen from the definite articles, which are like those selected with masculine nouns in the singular and with feminine nouns in the plural. This led some scholars to analyze this as a third gender in Italian too ((13a)):

(13) a. gender: Merlo (1952), Bonfante $(1961,1964,1977)$ : “Ci troviamo di fronte a un vero neutro." [We are facing a real neuter] (Bonfante 1961: 165);

b. 'inquorate' gender: Igartua (2006: 60);

c. inflectional class: Dressler \& Merlini Barbaresi (1994), Dressler \& Thornton (1996), D'Achille \& Thornton (2003): "Traditionally, phonological shape is the primary classifying criterion of nouns. This gives the following classes (or, often, microclasses): [...] v. gender-combined: masc. il bracci-o - pl. femm. le bracci-a 'arm.' (Dressler \& Thornton 1996: 5);

\footnotetext{
${ }^{13}$ While the inflections selected by this class of lexemes are inherited, the gender agreement pattern il braccio/le braccia first arose in the Latin-Romance transition (by the sixth century, according to Väänänen $1967^{2}: 111$ ). As shown in Faraoni et al. (to appear), the gender system was still tripartite in thirteenth century Florentine.
} 
d. derivation: Ojeda (1995), Acquaviva (2002, 2004, 2008): "I will argue instead that plurals in - $a$ do not belong to the inflectional system at all [...] My proposal is that they are lexical plurals [...] related to the base noun by a word-formation process." (Acquaviva 2008: 159)

However, there are today just a couple of dozen nouns that display the agreement pattern in (12), which led Igartua (2006: 60) to call it an inquorate gender ((13b)), applying Corbett's (1991: 170-175) category. Moreover, since all those nouns inflect the same way, another analytical option, taken by the scholars in (13c), treats them as just one inflectional class, not a separate gender. Finally, according to Ojeda (1995) and Acquaviva (2002, 2004, 2008) ((13d)), braccia is not an inflected form of braccio at all, but rather a distinct lexeme formed with a derivational suffix $-a$.

Synchronically, under analysis (13d) this collective suffix is comparable (despite some semantic differences) with -ata in e.g. una boccata 'a mouthful', from bocca 'mouth': "The - $a$ of braccia, then, does not carry inflectional information at all, and its status is that of a word marker." (Acquaviva 2008: 168). Diachronically, this analysis has run full circle with respect to early PIE, where ${ }^{*}-e h_{2}(>-\bar{a}>$ Lat. $-\breve{a}>$ It. $-a)$ was indeed a (non-inflectional) collective ending: in some sense, what Acquaviva is proposing is that the Italian suffix $-a$ has reverted to the function its PIE ancestor ${ }^{*}$-eh $h_{2}$ used to have, before getting 'drawn' into noun inflection as a neuter plural ending.

The argument in support of analysis (13d) is based on the one hand on the paucity of the class-members and on the other hand on the fact that "a common semantic denominator" (Acquaviva 2004: 153) seems to be traceable for the nouns in (12), which denote body parts ((12a)), members of cohesive aggregates, complexes of non-individual parts (like the sheets (of a bed)) or "objects perceived as indistinguishable" (Acquaviva's 2004: 258 characterization of 'eggs', (12b)), as well as several units of measure/quantity $((12 \mathrm{c}))$. We shall come back to (Acquaviva's account of) the semantics of these nouns in section 4.4, below. However, we shall not dwell any further on the standard language, since there are many Italo-Romance dialects which provide compelling evidence for a gender analysis of the classes of nouns corresponding to standard Italian il braccio/le braccia. 


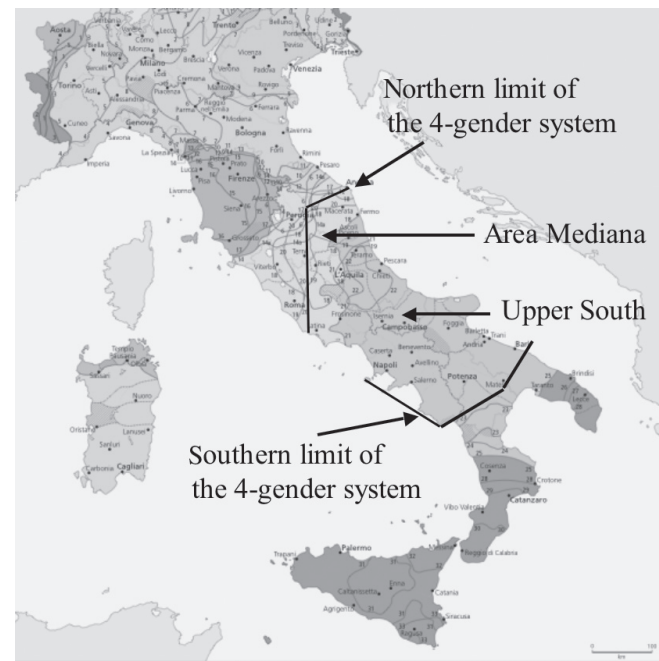

Figure 1. The area spanned by the four-gender system in Central-Southern Italy (based on Pellegrini's 1977 Carta dei dialetti d'Italia, elaborated in Loporcaro 2009a: 158).

\subsection{The alternating gender in the Italian dialects of} the Centre-South

Let us consider two dialects from the subdivision traditionally called the Centre-South, and in particular from the two subareas respectively called the Upper South, centring on Naples, and the Area Mediana, centring on Rome. (The map in Figure 1 shows the approximate limits of the area spanned by the gender system we are going to describe in what follows.)

The two sets of data in (14) and (15) are drawn respectively from the dialect of Avigliano (in Lucania) and that of Treia, near Macerata (in the Marche; see Paciaroni et al. 2008 for more detailed discussion of those two varieties). In both cases, all the nouns listed display the same agreement pattern (typical for a genus alternans), just like in Romanian ((10)) or Italian $((12))$. However, the dialect data differ from those of standard Italian (as highlighted in the schemes on the right-hand side in (14) and (15)) because the agreement pattern is shared by nouns belonging to several distinct inflectional classes: ${ }^{14}$ (See (22) below for the full picture of the gender agreement patterns in this dialect.)

${ }^{14}$ The singular form of the definite article $l u$ (prevocalically $l$ ) in (14) is identical to that selected with masculine nouns (e.g. l-u kwana/i, KKI kana 'DEF-M.SG dog(M)/DEF.M.PL 
(14) Noun inflectional (sub)classes displaying alternating agreement in Aviglianese (Nolè 2004-2005)

\section{Singular Plural}

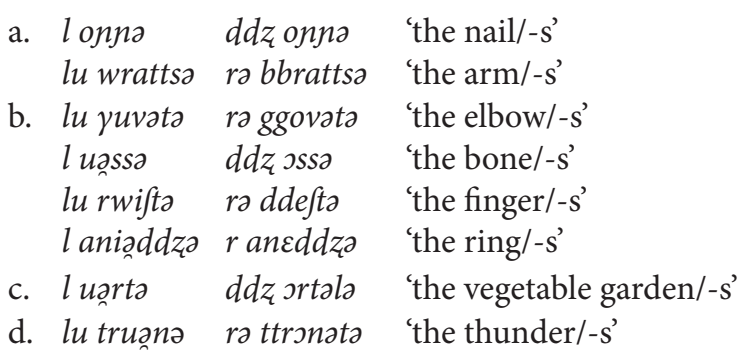

Sg. Pl.

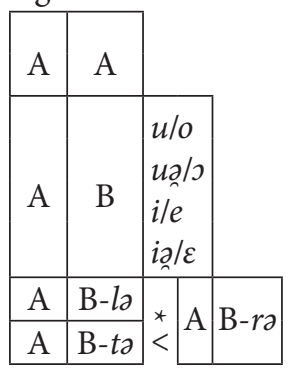

In Aviglianese a first class consists of nouns with identical forms for singular and plural ((14a)), which is symbolized in the scheme by the two identical capital letters. When the letters differ, as in (14b), this means that there is a formal distinction between the root forms occurring in the singular and in the plural. (Historically, this alternation arose through metaphony, which then became opacized, much like in English foot/feet.) Note further that in (14b) there are four different subclasses, distinguished by the occurrence of different vowel alternations. To the two inflectional classes (14a-b), two more have to be added $((14 \mathrm{c}-\mathrm{d}))$, which contain only one noun each. Both are residues of the -ORA plurals (arisen from the reanalysis of TEMPUS/ -ORA, mentioned earlier in section 3), a class that here all but disappeared, but is still alive and well in many neighbouring dialects (cf. n. 19).

Summing up, it is fair to conclude that in Aviglianese the alternating agreement pattern occurs with more than just one inflectional class, unlike in modern standard Italian. The same goes for the dialect of Treia, as shown in (15). Here too, selection of the definite article across the inflectional classes in (15) (sg. $\mathcal{u}$, pl. e) corresponds to what is found in the masculine singular (e.g. $u$ ðend-e 'DEF.M.SG tooth(M)-SG', pl. $i$ ðend- $i$ 'DEF.M.PL tooth(M)-PL') and in the feminine plural (e.g. e kas-e 'DEF.F.PL house(F)PL', sg. a kas-a 'DEF.F.SG house(F)-SG'). (See (23) for an overview of the gender agreement patterns occurring in Treiese.)

$\left.\operatorname{dog}(\mathrm{M})^{\prime}\right)$, whereas the plural form $r$ ( $r$ before unstressed vowels, $d d z$ before stressed vowels) is identical with that selected with feminine nouns: e.g. l ardika longa/ $\mathrm{r}$ ardika longa 'DEF.SG nettle(F) long $\backslash \mathrm{F} / \mathrm{DEF}$.F.PL nettle(F) long $\backslash \mathrm{F}$ ', $l$ aria $y$ rossa/ddz aria $y$ rossa 'DEF.SG barnyard(F) big $\backslash \mathrm{F} /$ DEF.F.PL barnyard(F) big $\backslash \mathrm{F}$ ': note that the allomorph $r$ causes RF of the following initial consonant. 
(15) Noun inflectional (sub)classes displaying alternating agreement in Treiese Singular Plural

a. i. $u$ vrattfu e vrattfa u muru e mura

ii. $u$ ditu e deta u tervellu e tfervella u lentsolu e lentsola

b. i. $u t f i j j u$ e trijie u soprattfijju

ii. $u$ vuðellu e soprattfijje u miðollu e vuðclle e meðっlle

Sg. Pl.

\begin{tabular}{|l|l|l|}
$\mathrm{A}-u$ & $\mathrm{~A}-a$ & \multicolumn{1}{|c}{} \\
\hline $\mathrm{A}-u$ & $\mathrm{~B}-a$ & $\begin{array}{l}i / e \\
e / \varepsilon \\
o / \jmath\end{array}$ \\
\hline $\mathrm{A}-u$ & $\mathrm{~A}-a$ & \\
\hline $\mathrm{A}-u$ & $\mathrm{~B}-a$ & $\begin{array}{l} \\
\end{array}$ \\
& $o / \varepsilon$ \\
\hline
\end{tabular}

In (15), two inflectional classes can be distinguished, based on plural inflection: in the former (15a), one finds in the plural the inherited morpheme $-a$ of Latin BRACHIA (e vrattfa), whereas in the latter (15b) this has been replaced by the $-e$ plural ending which occurs in first-declension feminine nouns. In the subclasses (15a-i) and (15b-i), singular and plural are distinguished only through affixal inflection. In (15a-ii) and (15b-ii), on the other hand, plural is distinguished not only by the endings but also by metaphony of the stressed vowel in the root. (This root-alternation is symbolized by the distinct capital letters $\mathrm{A} \neq \mathrm{B}$ in the scheme on the right-hand side.) All in all, we have two classes, each with two subclasses distinguished by the occurrence of non-affixal morphology (i.e. different root-vowel alternations).

For systems like those in (14) and (15), among the analyses considered for standard Italian in (13), the inflectional class analysis (13c) is clearly not viable, as those data cannot be reduced to just one inflectional class. Let us now see whether the derivational analysis (13d) fares better. Among the evidence for that, Acquaviva mentions the data in (16): $:^{15}$

a. il

dit-o

e il

bracci-o sono

DEF.M.SG finger(x)-SG and DEF.M.SG $\operatorname{arm}(\mathrm{x})$-SG be.PRS.3PL

stat- $i$

amputat- $i$

I *stat-e

*amputat-e

be:PTP-M.PL amputate:PTP-M.PL / be:PTP-F.PL amputate:PTP-F.PL

'The arm and the finger have been amputated.'

${ }^{15}$ Leipzig-style glosses force us to be explicit about the gender of the nouns. Following a suggestion by Greville Corbett we use 'gender x' for contemporary standard Italian, which is not at issue here, to imply that the situation is different from that of central-southern Italian dialects, for which we use 'A(LTERNATING)', as in (17)ff. 
b. l-e uov-a costa-no venti centesim- $i$

DEF-F.PL egg(X)-PL cost.PRS-3PL twenty cent(M)-PL

l' un-o /*l' un-a

DEF one-M.SG / DEF one-F.SG

'The eggs cost twenty cents each'.

c. l-e bracci-a di Ugo sono un-a più lung-a

DEF-F.PL $\operatorname{arm}(\mathrm{x})$-PL of Ugo be.PRS.3PL one-F.SG more long-F.SG

de-ll' altr-a / 'un-o più lung-o de-ll' altr-o.

of-DEF other-F.SG / one-M.SG more long-M.SG of-DEF other-M.SG

'Ugo's arms are one longer than the other.'

In (16a) it is shown that two coordinated NPs headed by alternating nouns select MPL, rather than FPL, agreement. This is unexpected, under the hypothesis that $-a$ plurals are just 'plain' (morphosyntactic) plurals: remember that each of those nouns requires feminine agreement in the plural. Similarly, (16b-c) show that agreement of distributive l'uno 'each' and reciprocal l'un l'altro 'each other' with plural NPs like le uova 'the eggs', le braccia 'the arms' is in the feminine singular, which is again unexpected, given an inflectional analysis of $-a$ plurals. ${ }^{16}$ Acquaviva (2008: 148) argues that this is evidence that we are facing what he calls a lexical plural (a collective), rather than a morphosyntactic inflectional plural:

If the feminine of certain nouns were just the automatically triggered consequence of their being plural, the distributive status of a morphologically singular pronoun should be irrelevant, and all mismatches in number between antecedent and pronouns should be equally acceptable or unacceptable. The observed crucial role of distributivity follows instead from the assumption that both the gender and the number value in uova are lexeme-inherent specifications. (Acquaviva 2008: 148)

\footnotetext{
${ }^{16}$ At this point the anonymous referee invites us to say more on the regional varieties of Italian which coexist, within the verbal repertoire, with dialects showing the syntactic behaviour deviant from standard Italian exemplified in (17)-(19). The issue is indeed an interesting one. Acquaviva's judgments correspond to ML's (a speaker of the Roman variety of Italian), whereas for the regional variety of Italian spoken in Treia, l'uno in (16b) and l'un l'altro in (16c) are perfectly acceptable. For the southern Italian speakers (from Calabria and Campania), on the other hand, consulted by the referee, the masculine is acceptable in (16b), not in (16c). Clearly, here, a systematic survey of regional differences would be required, which would exceed the scope of the present article. Such a study would be especially interesting because here we seem to have a prima facie case of persistence of different grammars across different subvarieties of Italian, depending on substratum influence from the local dialects, which is at odds with Acquaviva's (2000) claim that linguistic standardization throughout the Peninsula has now resulted in a single uniform syntactic competence, with only residual lexical differences persisting across (primary) Italo-Romance dialects.
} 
Now, this is indeed a solid argument for standard Italian, the prestige variety with which our dialects have been in contact for centuries. Thus, it will come as no surprise that the same option found in standard Italian is judged grammatical by speakers of our southern dialects too, as illustrated for Aviglianese in (17), where luąyga, akkuąvata, rutta are masculine forms (adjectives and participles do not mark number contrasts):
a. $\quad l-u$
wrattsa a $l-u$
rwifto
DEF-M.SG arm(A).SG and DEF-M.SG finger(A).SG
so llonga/lluagga.
be.PRS.3PL long $\backslash_{\mathrm{F}} /$ long $\backslash_{\mathrm{M}}$
'The arm and the finger are long.'
b. l-u rwijta a $l$ aniaddza $r$
DEF-M.SG finger(A).SG and DEF ring(A)\SG DO
add3 akkovatal akkuąvata.
have.PRS.1SG pick_up:PTP $\backslash F /$ pick_up:PTP $\backslash M$
'The finger and the ring, I picked them up.'
c. l-u wrattsa a l-u yuvata so
DEF-M.SG $\operatorname{arm}(\mathrm{A}) . \mathrm{SG}$ and DEF-M.SG elbow(A)\SG be.PRS.3PL
rrotta / rrutta.
break:PTP $\backslash$ F / break:PTP $\backslash M$
'The arm and the elbow are broken.'

Aviglianese

However, contrary to standard Italian, feminine agreement (loyga, akksvata, rotta) is here judged grammatical too, which cannot be attributed to standard Italian interference (given the Italian data in (16)).

Similar results can be replicated in the dialect of Treia with reciprocal and distributive pronominals, as well as the numeral 'one': ${ }^{17}$

\footnotetext{
${ }^{17}$ In Treiese, resolution with coordinated NPs belonging to the alternating neuter gender works like in standard Italian, as shown by categorical selection of masculine lungi in (ia), as opposed to feminine longe in (ib):

(i) a. $u$ dit-u $u \quad u$ vrattf-u aðć llung-i / DEF.M.SG finger(A)-SG and DEF.M.SG arm(A)-SG be.PRS.3 long $\backslash$ M-M.PL

*llong-e long $\backslash \mathrm{F}-\mathrm{F} . \mathrm{PL}$

'the finger and the arm are long'

b. $e$ det-a e e vrattf-a aðć llong-e /

DEF.F.PL finger(A)-PL and DEF.F.PL $\operatorname{arm}(\mathrm{A})$-SG be.PRS.3 long $\backslash \mathrm{F}-\mathrm{F} . \mathrm{PL}$

*llung- $i$

long $\backslash \mathrm{M}-\mathrm{M} . \mathrm{PL}$

'the fingers and the arms are long'
} 
(18)

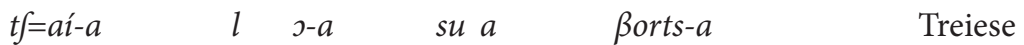
LOC=have:IMPF DEF egg(A)-PL on INDF.F.SG bag(F)-SG

ykartat-e un-u vitfino all addr-u / un-a vitfino wrap:PTP-F.PL one-M.SG near to-DEF other-M.SG / one-F.SG near a-ll addr-a.

to-DEF other-F.SG

'S/he kept the eggs wrapped in the bag next to each other.'

(19)
a. $l \quad s-a \quad k \jmath f t-a \quad$ sessanta tfentesim- $i$ DEF egg(A)-PL cost.PRS-3 sixty cent(M)-PL $l$ un- $u \quad / \% l \quad u n-a$.
DEF each-M.SG / DEF each-F.SG
'The eggs cost sixty cents each.'

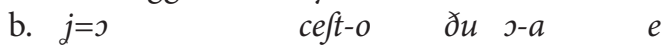 3OI=have.PRS.1SG ask:PTP-N two egg(A)-PL and
$m m e=n=a$
ðat-u
un- $u$ sul- $u$
$1 \mathrm{OI}=\mathrm{PRTV}=$ have.PRS.3 give:PTP-M.SG one-M.SG only $\backslash \mathrm{M}-\mathrm{M} . \mathrm{SG} /$
ðat-a un-a sol-a.
give:PTP-F.SG one-F.SG only\F-F.SG
'I asked for two eggs and she gave me only one.'

Here, similarly, the option coinciding with the standard (una) can be due to contact, but the symmetric one, with masculine singular agreement on the pronoun $(u n u)$, must be indigenous. Indeed, the latter is the option preferred by more conservative, elderly speakers.

To sum up, the tests leading Acquaviva to prefer a derivational analysis for the Italian plural le braccia yield the opposite result for our dialects. This confirms that the plurals we are discussing are just (inflectional) plurals, and that the consistent agreement pattern shared by the different inflectional classes in (14) and (15) has to be characterized as the manifestation of a (controller) gender. This in turn leaves us with the options $(13 \mathrm{a}-\mathrm{b})$. However, that the classes of nouns in (14) and (15) may belong to an inquorate gender can be excluded straightforwardly. For one such dialect, in fact, the one spoken in Molfetta (Apulia), Merlo (1917a) lists no less than 91 lexemes that select this alternating agreement pattern. (The abbreviation A stands, again, for 'alternating (neuter)'.). ${ }^{18}$

\footnotetext{
${ }^{18}$ As in many southern Italian dialects (see also (22), (33), (34)), the neuter form of the article causes RF of the following initial consonant.
} 
(20) Molfettese (Merlo 1917a)

\begin{tabular}{|c|c|c|c|c|}
\hline & Singular & Plural & & \\
\hline $\mathrm{N}$ & ra ffierra & & 'iron' & 49 lexemes \\
\hline M & $u$ fierra (da st rá) & la fierra (da st $\left.{ }^{2} r a ́\right)$ & 'the flat-iron/-s' & \\
\hline A & $u v^{2} t^{\partial} r \partial$ & ra vvetara & 'the glass/-es' & 91 lexemes \\
\hline & la $v \mathrm{~s}^{\partial} \mathrm{f}$ & ra $v v a^{u} \int \partial$ & 'the voice/-s' & \\
\hline
\end{tabular}

Note that the figures given for the two neuters (see directly below, section 4.2) in (20) are not exhaustive: Merlo (1917a) just provides an open list of lexemes by way of (qualitative) exemplification, without any attempt at quantifying. (Unfortunately, to the best of our knowledge no counts are available for present-day's Molfettese.) The issue of the threshold demarcating an inquorate from a 'normal' gender is a thorny one. As Corbett (1991: 172) puts it: "There can be no simple answer to this question". Anyway, the examples of inquorate genders adduced there from languages as diverse as Tsova-Tush, Serbo-Croat or Noni (a Grassfields Bantu language of Cameroon), range from one to about fifteen lexemes. Clearly, both neuters of Molfettese are much more robust than that.

\subsection{The four-gender system of the Italian dialects of the Centre-South}

The scheme in (20) also illustrates a quite surprising fact. Once we have recognized that these dialects have a genus alternans comparable with the Romanian (alternating) neuter ${ }^{19}$ then we are forced to admit that they have indeed four grammatical genders. These dialects, in fact, have long been

\footnotetext{
${ }^{19}$ As in Romanian, also in Molfettese (and, more generally, across the Southern ItaloRomance dialects displaying the four-gender system) lexemes selecting the alternating agreement pattern lexically belong in two main inflection classes: the singular ending of both classes stems from Lat. -UM (as in the inflectional class associated with masculine exemplified in the standard language by lupo, $i$ ' wolf/wolves'), whereas the plural endings go back to either -A (e.g. u gumata/ra ggomata < CUBIT-A 'the elbow/-s') or -ora (e.g. $u$ sicca/ra sseccara < ${ }^{*} \operatorname{SIT}(\mathrm{U}) \mathrm{L}$-ORA 'bucket/-s'; cf. Merlo 1917a: 81-82). (On the latter neuter plural ending, see section 3.) That words like gumata had a plural ending -A rather than $-\bar{I}$ - unlike the inflectional class associated with masculine gender exemplified in (20) with invariable fi ${ }^{e} r$ r $<$ sg. FERRUM $=$ pl. ${ }^{\star}$ FERRI - can be argued because of the non application of metaphony (pl. gomətz), which in these dialects affected mid vowels prior to final vowel neutralization.
} 
recognized to display still another gender, also a diachronic successor of the Latin neuter, viz. the so called 'neo-neuter', or 'mass neuter'. This is not 'just' a controller but even a target gender, since it has dedicated agreement forms in articles, personal pronouns and clitics, as well as demonstratives, as exemplified in (20) for Molfettese with the contrasting forms of the definite article: ra ffierra 'iron' (mass) as opposed to u fierra (da stará) 'the (countable) clothes-iron'. ${ }^{20}$ Note also that, although both deriving from the Latin neuter, the mass and the alternating Romance neuters are synchronically two fully distinct genders, sharing no exponent whatsoever in any agreeing word class: they consequently cannot fall together under the definition of gender in ( $7 \mathrm{a})$.

The same applies for all the dialects of the two subdivisions of ItaloRomance under discussion, including the two we have dealt with in section 4.1. In Avigliano and Treia, thus, there is not only, as we saw in (14) and (15), an alternating gender marked by article forms identical with the masculine in the singular and with the feminine in the plural, but there also is a third distinct form of the article before such mass nouns as 'bread':

\begin{tabular}{|c|c|c|c|c|c|}
\hline \multicolumn{3}{|c|}{ Aviglianese } & \multicolumn{2}{|l|}{ Treiese } & \multirow[b]{2}{*}{ 'the dog' } \\
\hline & $l-u$ & kwans & $u$ & $k a$ & \\
\hline & DEF-M.SG & $\operatorname{dog}(M)$ & DEF.M.SG & $\operatorname{dog}(M)$ & \\
\hline & $l-a$ & man & $a$ & & 'the has \\
\hline & DEF-F.SG & hand(F) & DEF.F.SG & hand(F) & \\
\hline & $r u / r a$ & $p p w a$ & $o$ & & 'bread' \\
\hline & DEF.N.SG & bread $(\mathrm{N})$ & DEF.N.SG & $\operatorname{bread}(\mathrm{N})$ & \\
\hline
\end{tabular}

It follows that masculine, feminine and mass neuter are separate target genders, marked with distinct agreeing forms. If one takes, in addition, the alternating neuter into account, as shown in (22) and (23), this adds up to a total of four genders.

\footnotetext{
${ }^{20}$ Note, however, that this kind of double gender assignment is by no means a general strategy obtaining across the lexicon to convey the mass-count distinction, contrary to what is claimed by Haase (2000: 227). At the very most, it goes as far as to involve about one third of the lexemes assigned to the mass neuter, as is the case in Maceratese (cf. dictionary counts in Paciaroni 2009). But in several of the other dialects under discussion (e.g. Agnonese), it just concerns a few lexemes. A list of mass nouns belonging to the neuter gender is provided by Ledgeway (2009: 150-154) for Neapolitan, though with a different analysis: in the author's view, in fact, Neapolitan has two genders, with the [ \pm count] distinction reducing to a purely semantic subdivision within the masculine (Ledgeway 2009: 150). The same analysis is defended by Maiden (2011: 701, n. 28).
} 
(22) Aviglianese

\begin{tabular}{|c|c|c|c|c|c|c|c|}
\hline \multicolumn{4}{|c|}{ Singular } & \multicolumn{3}{|c|}{ Plural } & \\
\hline$N$ & $r u / r o$ & ppwana & yruąssa & $\varnothing$ & & & 'the big (loaf of) bread' \\
\hline 1 & lu & kwañ & yruąssa & $i / K K i$ & kanə & yruasssa & 'the big dog/-s' \\
\hline 14 & lu & vrattso & yruąssa & ro & bbrattso & yrossa & 'the big arm/-s' \\
\hline & la & manə & yrossa & ra & mmanə & yrossa & 'the big hand/-s' \\
\hline
\end{tabular}

(23) Treiese

\begin{tabular}{|c|c|c|c|c|c|c|}
\hline \multicolumn{4}{|c|}{ Singular } & \multicolumn{2}{|l|}{ Plural } & \\
\hline N & $o p a$ & ggross- & $-O$ & $\bar{\varnothing}$ & & 'the big (loaf of) bread' \\
\hline$M$ & $u k a$ & ggross- & $-u$ & $i k a$ & ggross- $-i$ & 'the big dog/-s' \\
\hline A & u lentsolu & yross- & $-u$ & e lentsola & yross- $-e$ & 'the big bed sheet/-s' \\
\hline$F$ & $a m a$ & ggross- & $-a$ & $e m a$ & ggross- - e & 'the big hand/-s' \\
\hline
\end{tabular}

We have already seen that this alternating neuter has to be considered a gender in its own right, as the words selecting that agreement pattern cannot be reduced to one single inflectional class nor can their plurals be regarded as derivational. In (24) we now show, with examples from Treiese, that the mass neuter is also a gender in its own right, lexically, semantically and syntactically:

(24) Productivity of mass neuter (Treiese)

a. Adaptation of recent loan words: e.g. o fporta 'the sport'.

b. Nominalization (by conversion): o manná 'the eating' $(\mathrm{V} \rightarrow \mathrm{N})$; o ftúbbeto 'the stupidity', o prefto 'the soon-ness, earliness' $(\mathrm{Adv} \rightarrow \mathrm{N})$; kampa su o sua 's/he lives on what her/his smallholding can produce', lit. 's/he lives on her/his (smallholding)' (Pron $\rightarrow \mathrm{N}$ ).

c. Agreement with non canonical controllers:

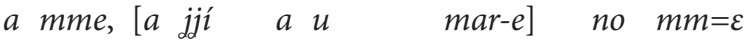

to 1 SG.IO to go.INF to DEF.M.SG see(M)-SG NEG 1SG.IO=be.PRS.3

mmaj pjatfut-o.

never please:PTP-N

'I never liked [going to the see].'

From a lexical point of view, we can observe that the mass neuter is productive, as recent loans still get assigned to it ((24a)). This gender is also endowed with a straightforward semantic definition as well as with specific syntactic properties. Semantically, it hosts only non-countable nouns, and nominalizations of other parts of speech are assigned to it ((24b)), which is typical for a neuter gender serving as a default. Also, neuter agree- 
ment $((24 \mathrm{c}))$ occurs with non-canonical controllers like clausal subjects or objects. ${ }^{21}$ This is typical too, for a neuter, in a system where it is the (syntactic) default gender (for example, Russian, German, Icelandic etc.), as documented by cross-linguistic studies such as Corbett (1991: 203-207), Corbett \& Fraser (2000: 70-87). In this literature, both gender assignment under conversion $((24 \mathrm{~b}))$ and agreement with non-prototypical controllers $((24 \mathrm{c}))$ are pointed out as criterial properties of default genders.

\subsection{The four-gender system in a typological perspective}

Though our conclusion that Central-Southern Italo-Romance dialects have four genders may be quite striking within a IE perspective, we are by no means postulating a typological oddity. ${ }^{22}$ There are several lan-

${ }^{21}$ While the data in (24) are representative of the situation in the Area Mediana, the varieties of the Upper South present some further complications. For instance in some dialects of Campania (like those of Cetara, Ravello, Scala, as reported in Avolio 1996: 313) some originally feminine nouns, either count ( $a$ nstta 'the night') or mass ( lana 'the wool'), can be recategorized as mass neuters: o nnotta 'the darkness', o llana 'the wool'. While this recategorization is restricted to just a few lexemes (and is possible in some dialects only), in most dialects of Campania, including Neapolitan (see e.g. De Blasi \& Imperatore 2000: 72-73; De Blasi 2002: 117; 2006: 9, 38-40; Maturi 2002: 236; Ledgeway 2009: 153-154), feminine mass nouns may be anaphorically taken up by means of a neuter pronoun, while preserving feminine agreement on articles/determiners:
a. $a$
karno
niffuna
bbo.
DEF.F.SG meat(F).SG nobody DO.N want.PRS.3SG
'The meat, nobody wants it.'
b. a muttsarello o kkatto tu.
DEF.F.SG mozzarella(F).SG DO.N buy.PRS.2SG 2SG
'The mozzarella, you buy it.'

What is found in (i) is an incipient instance of semantic agreement, whereby the semantic feature [-count] overrides the gender specification of feminine (mass) nouns in determining the selection of the neuter object clitic. The fact that this semantic agreement does not affect the NP is in keeping with the agreement hierarchy (Corbett 2006: ch. 7). Anyway, neither of the two facts described now for Campanian is encountered in dialects of the Area Mediana like Treiese. (Thanks to the anonymous referee for discussing this point with us.) ${ }^{22}$ Even within IE, though general surveys set a maximum of three genders as seen in sections 1 and 2, there seem to be (on some analyses) gender systems comparable with the ones we are describing. Albanian (cf. Breu to appear), in addition to masculine and feminine, has a neuter to which several mass nouns are assigned (e.g. djathë 'cheese') as well as countables such as krye 'head', alongside an alternating neuter of the Romanian kind (e.g. vend, vende, 'place/-s', mall, mallra 'ware/-s') taking masculine agreement in the singular and feminine in the plural. Both neuters are productive, the former being fed by conversions (e.g. tëftohët 'the cold', të folurit 'the [act of] speaking'), the latter by the productive suffix -im deriving abstract nouns (e.g. kujtim, kujtime 'memory/memories', from kujtoj 'to remember'). 
guages of the world with four genders, two of which are reserved to nonhumans. This is the case in several languages of Australia, as exemplified with Worora (a non-Pama-Nyungan language of North-Western Australia; cf. Love 2000: 15-22, Dixon 2002: 476), nearby Ungarinjin (cf. Rumsey 1982: 31-39) or, still within non-Pama-Nyungan, the Kunwinjku dialect of Mayali, which has four genders, comprising I masculine, II feminine, III vegetable and IV neuter (Evans et al. 2002: 116). Consider the Worora examples in (25):

(25) Worora

\begin{tabular}{|c|c|c|c|}
\hline & Positive & Negative & 3SG personal pronoun \\
\hline Masculine & 'indja & 'kaui & $\begin{array}{l}\text { Male human beings and important } \\
\text { animals (but also 'moon', 'spear', etc.) }\end{array}$ \\
\hline Feminine & 'nijina & 'njuygi & $\begin{array}{l}\text { Female human beings and important } \\
\text { animals (but also 'sun', 'whale', etc.) }\end{array}$ \\
\hline Neuter $_{1}$ & 'wuna & 'kui & $\begin{array}{l}\text { Less important animals and inanimate } \\
\text { objects }\end{array}$ \\
\hline Neuter $_{2}$ & 'mana & 'maui & $\begin{array}{l}\text { Less important animals and inanimate } \\
\text { objects }\end{array}$ \\
\hline
\end{tabular}

Worora has overt gender on the noun and marks gender agreement on verbs, adjectives and pronouns (exemplified in (25) with the positive vs. negative $3 \mathrm{SG}$ forms). ${ }^{23}$ As shown in (25), the masculine and feminine genders have a semantic core, but also a substantial portion of idiosyncratically assigned lexemes. In the masculine gender several nouns are found that denote objects which can be in some way associated with manliness (e.g. tji'nælja 'spear', 'adja 'rain', 'kınımıri 'shark'), as well as the word for 'moon' ('kunjila), whereas 'mırıуunja 'sun' is feminine (a polarity widely attested cross-linguistically; cf. Lazzeroni 1993: 82, Aikhenvald 2000: 23). On the other hand, no semantic criterion is at work to discriminate between the two neuters (Love 2000: 21). The semantics here are the same, as (nearly) synonymous words are assigned to either of the two genders for non-humans: e.g. bi'nalu 'ash' is neuter ${ }_{1}$ whereas pimbi'nılba, also 'ash', is neuter ${ }_{2}$; 'anu

\footnotetext{
${ }^{23}$ More precisely, consistent overt gender is to be found on feminine nouns, as they all end in -nja or -dja (Love 2000: 21). For the remaining three genders there are simply statistical correlations with the phonological shape of the word (Dixon 2002: 476): about 50 per cent of masculine nouns ends in $-y a$ or $-i$, about 80 per cent of neuter ${ }_{1}$ nouns (called wunanouns by the natives) ends in $-b,-b a,-m$ or $-m a$, while about 55 per cent of neuter ${ }_{2}$ nouns (called mana-nouns) ends in $-g u$ or $-u$.
} 


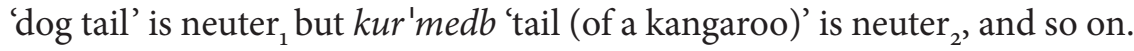
The only reliable criterion is phonological: the nouns assigned to neuter ${ }_{2}$ end in a labial consonant, possibly followed by $-a$, whereas nouns ending in non-labial consonants (possibly followed by $-u$ ) are neuter ${ }_{1}$. As observed by Dixon (2002: 476), this parallels the phonology of gender agreement, which is realized on most adjectives through affixal morphology whose phonological shape is respectively $m a$-base- $m(a)$ for neuter ${ }_{1}$ vs. $w u$-base$(u)$ for neuter ${ }_{2}$. Ungarinjin too has exponents of gender agreement phonologically similar to the Worora ones, though no cues whatsoever of overt gender are found on Ungarinjin nouns, neither for the two neuters nor elsewhere in the gender system (cf. Rumsey 1982: 31, 39-41).

The lack of a semantic criterion for assigning nouns to either of the two neuters distinguishes the Worora system from the one we have come up with for our Italo-Romance dialects, where a straightforward semantic characterization is found for the mass neuter, and also the alternating neuter can be defined, at least in a first stage, in loosely semantic terms (see (27) below). The existence of a semantic distinction between the two neuters makes our Romance four-gender systems more similar to the one of Burushaski, mentioned above in (1). A further similarity is the possibility for gender recategorization of some roots/lexemes. For instance, in Burushaski the same root (e.g. bayú 'salt', or -úl 'intestine') can form nouns of either (non-human) gender (cf. Lorimer 1935: 14-25; Berger 1998: 81-82, 100-102; Grune 1998: 3):
(26) Count
Mass
bayú (NEUTER $)_{1}$ 'lump of rock salt'
$\neq\left(\right.$ NEUTER $\left._{2}\right)$ 'salt'
-úl 'intestine $\left(\right.$ NEUTER $\left._{1}\right)$ of living animal' $\neq\left(\right.$ NEUTER $\left._{2}\right)$ ' $\ldots$ of dead animal'

A comparable double categorization is to be found with some lexemes (e.g. 'iron', see (20) and n. 20) in Central-Southern Italo-Romance dialects. The difference is that in Romance the count option corresponds to masculine, rather than to the second neuter gender, which is possible because Romance gender is semantically largely idiosyncratic, in keeping with the general situation of Indo-European languages. ${ }^{24}$

\footnotetext{
${ }^{24}$ On the contrary, as said in section 1 (see (1)), the Burushaski system is semantically based, since there is a biunique correspondence on the one hand between nouns denoting humans of either sex and the masculine/feminine genders respectively, and a (tendentially) biunique correspondence on the other hand between nouns denoting count objects and
} 


\subsection{The rise of the four-gender system}

Let us now revert to the IE language-family, to see how the four-gender systems we have described fit into the overall IE picture seen in (5) above. We have seen that the three inherited genders tend, if anything, to reduce across the IE languages, and becoming four admittedly seems, at first glance, to be quite the opposite development. Yet, it can be argued that the change that led to the four-gender system of Central-Southern ItaloRomance is actually part of one and the same drift as the one that led to the modern systems of French, Italian or Spanish (type (5b-i), exemplified with Sardinian in (8) above). Here the three-gender system shrunk through the demise of the neuter, whose members were reassigned to either the masculine or the feminine. ${ }^{25}$

In our dialects too, one has to assume a break-up of the Latin neuter: this, however, did not just dissolve, it rather split into two distinct new genders, viz. those we have called alternating neuter vs. mass neuter in (22) and (23). These both selectively inherited formal and functional features of the Latin neuter.

As for the semantics, the neuter had become in Latin a partly idiosyncratic gender, containing even nouns denoting human beings, like e.g. scortum 'prostitute', synonymous with (feminine) meretrix. Yet, there were two large semantic clusters, which Belardi (1950: 208) labelled synthetic vs. analytical collective, as shown in (27a-b). The former label refers to mass nouns like mel 'honey', the latter to pluralia tantum or, more loosely, plurals denoting sets of weakly differentiated parts, as exemplified by pecua, which is morphosyntactically a plural (of pecu 'domestic animal') but just means 'herd, flock'.

Of course, there were also Latin countable nouns that were assigned neuter gender (e.g. collum 'neck', tectum 'roof', etc., $(27 \mathrm{c})$ ), but in the LatinRomance transition those countable lexemes were normally recategorized as masculine (see n. 25), whereas this was not the case for collectives of the

animals vs. mass nouns and the two neuter genders. To be sure, some idiosyncrasies in gender assignment are found in Burushaski too, since for certain object-denoting nouns the assignment to either of the two neuters is not the one we would predict from the semantics. The handful of exceptions include e.g. íram 'cream' (neuter ${ }_{1}$ though mass), or ha 'house', asgór 'flower' (neuter ${ }_{2}$ though count, at least in our culture).

${ }^{25}$ While the former was the default option (e.g. Folium > It. foglio 'sheet(M) (of paper)'), the latter change took place in case an originally inflectional - $a$ plural was lexicalized as the new base of a distinct lexeme (e.g. FOLIA > It. foglia 'leaf (F)'). 
(27)

\begin{tabular}{|c|c|c|c|}
\hline & & i. Latin & $>$ \\
\hline a. & $\begin{array}{l}\text { synthetic } \\
\text { collective }\end{array}$ & $\begin{array}{l}\text { ILLUD } \\
\text { MEL }\end{array}$ & 'honey' \\
\hline b. & $\begin{array}{l}\text { analytical } \\
\text { collective }\end{array}$ & $\begin{array}{l}\text { ILLA } \\
\text { PECUA }\end{array}$ & 'the flock' \\
\hline c. & $\begin{array}{l}\text { countable } \\
\text { nouns }\end{array}$ & $\begin{array}{l}\text { ILLUD } \\
\text { TECTUM }\end{array}$ & 'the roof' \\
\hline
\end{tabular}

ii. PRom > iii. C-S Italo-Romance

\begin{tabular}{|l|l|}
\hline \multirow{2}{*}{ neuter } & (mass) neuter \\
& alternating neuter \\
\hline to the masculine \\
\hline
\end{tabular}

two kinds, which at a first transitional stage (27ii) must have stuck to the neuter. ${ }^{26}$ In a further diachronic step, then, which is (partly) preserved to this day in the Italo-Romance dialects of the Centre-South, the two central semantic clusters of the Latin neuter split ((27iii)), yielding the two neuters: ${ }^{27}$ the mass neuter inherits the 'synthetic collective' semantic value whereas the alternating neuter inherits what Belardi calls the 'analytical collective' one. Many of the nouns in this class, in fact, are captured by the 'common semantic denominator' Acquaviva proposes for all the different subclasses of modern standard Italian lexemes (exemplified in (12)) which retained the alternating pattern braccio/braccia:

the parts making up the denotation [of - $a$ plurals] are conceptualized as undifferentiated, in different ways according to the lexical semantics of the noun. (Acquaviva 2008: 153)

This description - Acquaviva argues - applies equally well to 'eggs', measure words, collectives like mura 'walls', cohesive aggregates like body parts, etc. But although the circumstance of having a plural that matches the above semantic definition might well have helped inclusion (or retention) of a given lexeme in the alternating neuter gender, the evidence from

\footnotetext{
${ }^{26}$ This is the crucial claim laid out in the present article, against the vulgata in historical Romance linguistics, according to which the neuter gender dissolved as such already in the late Latin/Proto-Romance stage. One notable exception is Kuryłowicz (1964: 212), according to whom in an early (pre-documentary) period Italian still had a tripartite gender system, including a neuter, whose exponents on adjectives and articles were $-o$ sg./ $-a \mathrm{pl}$.

${ }^{27}$ See Lorenzetti (1995: 81-117) for an application of Belardi's distinction to the fate of the Latin neuter in Central-Southern Italo-Romance dialects. There is evidence that the split of the neuter ((27iii)) might have occurred more generally across Romance (perhaps at a late stage of PRom), as all Romance branches still show both remnants of neuter (singular) agreement (in default contexts), as well as remnants of neuter (plural) agreement with outcomes of Latin - $a$ plurals. Discussion of this comparative evidence would exceed the scope of the present article.
} 
Central-Southern Italo-Romance dialects clearly shows that this was never a necessary condition. What unites all nouns which display the alternating agreement pattern in those dialects is not (anymore) a common semantic denominator but simply the fact that they share a common gender agreement pattern, and hence satisfy the definition of gender in ( $7 \mathrm{a})$. That the semantics is non-criterial here is easily demonstrated by the lists of alternating neuter lexemes provided e.g. for Molfetta by Merlo (1917a: 81-83),

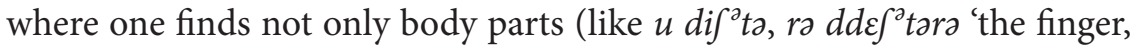
$\left.-s^{\prime}\right)$, or nouns whose plural have a mass interpretation (like $u t f \partial r \partial v i^{e} d d$, ra $t$ tfaravedd ${ }^{2} r$ ' the brain,-s'), but also a great number of nouns denoting countable objects $((28 \mathrm{a}))$ - whose plurals cannot possibly be conceptualized as denoting sets of "weakly individualized referents" (Acquaviva 2004: $262)$ - and even nouns denoting animate referents $((28 b)):^{28}$

(28) Molfettese

Singular Plural

a. $u$ kartie dda rakkartedd ${ }^{2} r$ 'the knife, -s'

u lietto rallettara 'the bed, $-\mathrm{s}$ '

u trajaina rottrajenara 'the cart, $-\mathrm{s}$ '

$u$ vardi ${ }^{e} d d$ ro vvarded ${ }^{3} r$ o 'the pack-saddle, $-\mathrm{s}^{\prime}$

b. u gardi ddo ra ggardedd $r a$ 'the cock, $-\mathrm{s}$ '

$u$ gattuddo ra ggattodd ${ }^{2} r$ 'the kitten, $-s$ '

upartfa $a^{i}$ a rappartfenara 'the chick, -s'

u tfutts ro ttjottfara 'the donkey, -s'

In some dialects of Central-Southern Italy, furthermore, the alternating neuter (and the noun inflection classes correlating with it) attracted nouns denoting not only animate referents but even human beings, thus becoming conventionalized (i.e. semantically idiosyncratical). A case in point is that of the dialect of Agnone (Molise), whose four-gender system is schematized in (29):

(29) Agnonese

\begin{tabular}{|c|c|c|c|}
\hline & Singular & Plural & \\
\hline $\mathrm{N}$ & la moila & $\varnothing$ & 'honey' \\
\hline M & ru kafeuna & ro kafiuna & 'the peasant, -s' \\
\hline A & ru landzuora & la landzeure & 'the bed-sheet, -s' \\
\hline $\mathrm{F}$ & la volpo & la vulpa & 'the fox, -es' \\
\hline
\end{tabular}

${ }^{28}$ The same applies to the data seen in section 4.1, above: for instance, in Aviglianese $((14 \mathrm{c}-\mathrm{d}))$, the words for 'vegetable garden' and 'thunder' belong in this gender class. 
While in (29) the alternating neuter is exemplified with the word for 'bedsheet' (and one could add the usual suspects, including e.g. $r$ uovo, l euwe 'the egg, -s', names of body parts like ru januocca, la janoccare 'the knee, -s', etc.), (30) shows that the words for 'wolf', 'bear' and even 'husband' and 'snotty-nosed (lad)' belong in this gender class too (cf. Ziccardi 1910: 426, Meo 2003: 127, 134, 241; variation in the form of the (alternating) definite article is purely phonological):

(30) Agnonese

$\begin{array}{lll}\text { Singular } & \text { Plural } & \\ \text { ru liupa } & \text { la lopare } & \text { 'the wolf, -ves' } \\ \text { l urtsa } & \text { lortsare } & \text { 'the bear, -s' } \\ \text { ru maroita } & \text { la maretare } & \text { 'husband' } \\ \text { ru farfiusa } & \text { lo farfosare } & \text { 'snotty-nosed (lad)' }\end{array}$

To conclude on this point, while there might have been some tendency for Latin neuters to stay in the alternating gender (rather than migrate into the masculine) in case they had the semantics described in $(27 \mathrm{~b})$, this was by no means a necessary requirement. In order to characterize this (ItaloRomance) gender, we rather have to resort to morphosyntactic properties, viz. the agreement pattern they trigger on associated words.

In this domain too, the two Italo-Romance neuter genders provide evidence for the split inheritance of Latin neuter morphological structures, as seen with the etymological sources of the definite articles in (31) and (32):

(31) Late Latin, Stage 1

\begin{tabular}{|c|c|}
\hline Singular & Plural \\
\hline $\operatorname{ILLU}(M) \operatorname{LOCU}(M)$ & ILLI LOCI \\
\hline $\operatorname{ILLA}(\mathrm{M}) \operatorname{MENSA}(\mathrm{M})$ & ILLAE/ILLAEC MENSAE \\
\hline $\operatorname{ILLU}(\mathrm{D}) /{ }^{*} \operatorname{ILLOC}{ }_{\text {MEL }}^{\text {MEMBRU(M) }}$ & ILLA/ILLAEC MEMBRA \\
\hline
\end{tabular}

(32) Late Latin, Stage 2

\begin{tabular}{|c|c|c|c|}
\hline & Singular & Plural & \\
\hline M & $\operatorname{ILLU}(M) \operatorname{LOCU}(\mathrm{M})$ & ILLI LOCI & 'the place, $-s$ ' \\
\hline $\mathrm{F}$ & $\operatorname{ILLA}(\mathrm{M}) \operatorname{MENSA}(\mathrm{M})$ & ILLAE/ILLAEC MENSAE & 'the table, $-s$ ' \\
\hline $\mathrm{N}_{1}$ & $\operatorname{ILLU}(\boxplus) /{ }^{*} \amalg \amalg \Theta \in$ MEMBRU $(M)$ & ILLA/ILLAEC MEMBRA & 'the $\operatorname{limb},-s$ ' \\
\hline $\mathbf{N}_{2}$ & $\operatorname{HLU}(\boxplus) /{ }^{\star}$ ILLOC MEL & & '(the) honey' \\
\hline
\end{tabular}

In a first stage (31), that we can call Late Latin 1, the gender system is still the familiar tripartite one, but the agreeing determiner (article) paradigms 
show several non-functional cell-mates (i.e. couples of inflectional word forms in free variation), ${ }^{29}$ partly inherited, partly due to analogical innovation. In the plural, ILLAEC had been competing with ILLA ever since the archaic period (Plautus, third century BC). There are several occurrences of NPL illaec (v. ThLL VII 370-371): e.g. cum illaec sic facit 'while he makes this' (lit. 'those things that way'; Pl. Cist. 290); ubi illaec quae dedi ante 'where are those (it refers back to duo talenta 'two talents(N)') that I gave before?' (Pl. As. 196); sumne ego mulier misera, quae illaec audio? 'aren't I a poor woman, since I have to listen to those things?' (Pl. As. 196). The same neuter plural morphology is attested for iste 'this' too: ioculo istaec dicit 'he says those things as a joke' (Pl. St. 24). The feminine nominative plural illaec occurs in Pl. Cur. 398: illaec catapultae ad me crebro commeant 'those catapults often bomb me'.

Neuter singular ${ }^{\star}$ ILLOC, on the other hand, competing with classical ILLUD, is not attested but must be reconstructed (cf. Merlo 1906-1907, 1917a) given two pieces of evidence from the Romance outcomes: first, final $-o$ in the neuter determiner endings in dialects like Treiese (see e.g. $o p a$ 'the bread' in (23)); secondly, RF in dialects like Aviglianese (see ru ppwana 'the bread' in (22), Molfettese (see ra ffierra 'iron' in (20)), or Neapolitan, whose gender system is schematized in (33) (cf. Merlo 1917b: 105-111):

(33) Neapolitan

\begin{tabular}{|c|c|c|}
\hline Singular & Plural & \\
\hline N. o ffierra & & 'iron’ (mass) \\
\hline M. o fjerra & e fjerra & 'the iron, $-s$ ' (count.) \\
\hline A. o lavra & e llavra & 'the lip, -s' \\
\hline F. a krotø & e kkrut љ & 'the cross, -es' \\
\hline
\end{tabular}

In present-day Neapolitan, the forms of the definite article are phonetically identical (o) for the masculine singular and the (mass) neuter, except that the latter, unlike the former, causes RF ( o ffjerra 'iron'). Classical Latin ILLUD would account for this phonological property of southern dialects (since final -D became assimilated in sandhi, just like final -C), but could

\footnotetext{
29 These are traditionally labelled 'doublets', but the term is ambiguous, being also used for non-synonymous lexemes with shared etymology (cf. the discussion by Thornton 2009). Therefore, we propose to call cell-mates any two (or more) distinct forms realizing the same cell in one and the same inflectional paradigm (e.g. ILLA/ILLAEC for the cell defined by the morphosyntactic feature values 'nominative/accusative neuter plural' in (31)).
} 
not possibly account for the - $o$ vs. $-u$ distinction in (23), since short final - $U$ should have developed the same way as in the masculine form ILLUM (pace Lüdtke 1965; compelling arguments against Lüdtke's view are provided by Campanile 1973). On the other hand, an analogical ${ }^{\star}$ ILLOC, built on the model of HOC, accounts for all facts. That new pronominal forms were indeed formed on the analogy of hoc is demonstrated by istoc (alongside classical istud), documented again in Pl. Bac. 382 (cf. Merlo 1917a: 92).

The rise of analogical forms such as ${ }^{\star} i l l o c$ in late Latin, as well as the increased vitality of illaec, flies in the face of recent analyses by generative syntacticians who claim (in one form or other) that neuter was no longer a real gender in Latin (e.g. Pescarini 2008, Pomino \& Stark 2007). Such analyses appeal to the fact that, in classical Latin, neuter plural bon- $a$ has an ending which is not biuniquely dedicated: for instance, it also occurs in the feminine singular. Ultimately, confusion between gender and inflectional class is at play here: true, in the neuter (agreement) paradigm there were forms like bon-u-m, bon-a(-m), but there were also, in other inflectional classes, id, quod, quid, istud, illud, hoc, haec, which were dedicated forms. Some of these even provided the model for analogical innovations, such as ${ }^{*}$ illoc, that must be reconstructed, as we saw, on the evidence from CentralSouthern Italian (as well as Asturian dialects of Ibero-Romance: cf. Loporcaro 2009b). Clearly, neuter agreement morphology was still developing innovations until a late stage in the Latin-Romance transition.

In the later development of the Italo-Romance varieties under discussion, a further step in this transition can be reconstructed as shown in (32). The neuter split into two distinct genders, of which we have already seen the semantic characterization in (27). These are genders on a par with masculine and feminine, not subgenders of the kind familiar from e.g. the Slavic languages (see section 2). In a seemingly paradoxical way, the reason why our Italo-Romance dialects must be ascribed a more complex (main) gender system than Slavic languages such as Russian is the lesser overall complexity of Romance, as opposed to Slavic, nominal inflection. In a language like Russian, noun inflection is a strong predictor of gender (Corbett 1982: 215-227, Corbett 1991: 34-43). Now, there are several inflectional endings shared by [ \pm animate] masculine nouns which therefore as a whole satisfy the definition of an inflectional class in ( $7 b$ ) (and since the language has by and large overt gender, this also carries over to gender, as is indeed reflected in target agreement). In fact, [ \pm animate] inflection in both nouns and agreeing words part ways only in the accusative ending. All this is 
made possible by the rich nominal inflection of Russian (and most Slavic languages). In other words:

Subgender appears to be intimately connected with case, because the presence of case features means that it occurs only in a minimal subset of the paradigm. (Brown 1998: 220)

This prerequisite is missing in Romance: in the systems under discussion here there is, as it were, not enough morphological room for a layered structuring of the gender (and subgender) distinctions, so that for instance in (23) (Treiese) there is just a binary contrast between $u k a$ 'the.M $\operatorname{dog}(\mathrm{M})^{\text {' }}$ and $o p a$ 'the.n bread $(\mathrm{N})$ '.

With the split of the Latin neuter into two distinct genders, a selection of the available neuter agreement forms, formerly in free variation, took place, as shown in (32). In the singular, the two former variants get specialized: ${ }^{\star}$ ILLOC develops into the marker of the mass neuter, whereas ILLUD specializes as a marker of what was going to become the alternating neuter. The first step towards the establishment of this alternating neuter gender was taken as ILLUD merged with masculine ILLUM, through deletion of the final consonant. The modern outcome of this diachronic development, as we saw in (20), (22), (23), (29) and (33), is a four-gender system with, among others, a controller gender of the Romanian type. However, at stage (32), this is not yet the case, since what was later to become an alternating gender (still) had dedicated plural agreement forms. This situation persisted well into the documented history of the Romance languages, as becomes apparent as soon as we consider Old Neapolitan (thirteenth to fifteenth centuries), and compare it with the modern dialect data seen above in (33). Here is a sketch of the gender system in the Medieval variety (after Formentin 1998: 292 n. 844, 304, 315-319): ${ }^{30}$

\footnotetext{
${ }^{30}$ While dividing lines in (34) denote contrasts between agreement targets, a dotted line in the plural separates nouns such as vrazzo 'arm' - whose plural vrazza can take at that diachronic stage either a dedicated plural agreement form (la, for the article) or a feminine form (lle) in free variation - from feminine nouns which categorically select the latter. Parenthesized initial consonants in (34) stand for the application of RF, brought about by the neuter ${ }_{2}$ and the feminine plural articles, that was first explained by Merlo (1906-1907, 1917a) by assuming the etyma ${ }^{*}$ ILLOC and ILLAEC respectively. Here, none of the conceivable alternatives - ILLAE, ILLAS, or hybrid ${ }^{\star}$ ILLAES - could possibly account for RF. Although RF is only desultorily reflected in Old Neapolitan texts, it can be reconstructed crossing the written evidence with the reconstructive argument provided by the correlation between preservation of geminate $l l$ and the application of RF itself (cf. Formentin 1994).
} 
(34) Old Neapolitan

\begin{tabular}{|c|c|c|c|c|c|}
\hline \multirow[b]{2}{*}{$\mathrm{N}_{2}$} & \multicolumn{2}{|c|}{ Singular } & \multicolumn{2}{|c|}{ Plural } & \\
\hline & llo & (b)bene & & & \\
\hline M & lo & nimico & li & nimice & 'the enemy, -ies' \\
\hline $\begin{array}{l}\mathrm{N}_{1} \\
(>\mathrm{A})\end{array}$ & lo & vrazzo & la & $\begin{array}{l}\text { vrazzal } \\
\text { (b)brazza }\end{array}$ & 'the arm, -s' \\
\hline & la & donna & lle & (d)donne & 'the lady, -ies' \\
\hline
\end{tabular}

In the modern dialect, the feminine plural article is an outcome of ILLAEC, attested in Latin as a rarer variant competing with classic ILLAE (see above). For the neuter ${ }_{1}$ plural, on the other hand, the competition was between ILLA and ILLAEC: while the latter was homophonous with the feminine plural non-classical form which eventually won out in Neapolitan (see in (33) e kkrut $f$ < ILLAEC CRUCES 'the crosses(F)' = e llavra < ILlAEC LABRA 'the lips(A)'), the former was peculiar to the neuter. In other words, as long as $l a<$ ILLA (and similar neuter plural agreeing forms) persisted, the Central-Southern neuter had not reduced yet to a controller gender, but still remained a target gender. That this was indeed the case at least until the end of the Middle Ages is shown by examples like the following:

(35) Bagni di Pozzuoli (cf. Pelaez 1928) Old Neapolitan, late 13th-early 14th c. doglla face a la latora 243 'it causes pain in the sides', sola chesta locora ne poteno sanare 15 'only (adj.) these places can cure us', chesta bagnora 103 'these baths', chesta dicta omnia 64 'all these things said (until now)', trovano sua disia 200 'find (satisfaction to) their wishes'

The data stem from a late thirteenth century text, but similar examples occur even later, as shown by Formentin (1998: 292-293; from the Ricordi by Loise De Rosa, fifteenth century Neapolitan, 58v6):

(36) seno l-a mur-a nonso bell-e, tutt-e l-e if not the-NPL wall $\left(\mathrm{N}_{1}\right)$-PL not be.PRS.3PL beautiful-F.PL all-F.PL the-F.PL altr-e so mirabbelemente.

other-F.PL be.PRS.3PL wonderful

'Even if the walls are not beautiful, all other (things) are wonderful.'

As shown in (36), at that stage (and even later) one still finds plural verbal agreement with NPs like la vrazza in (34). This demonstrates unambiguously that $l a$, chesta etc. are dedicated plural agreement markers of a target 
$(37)$

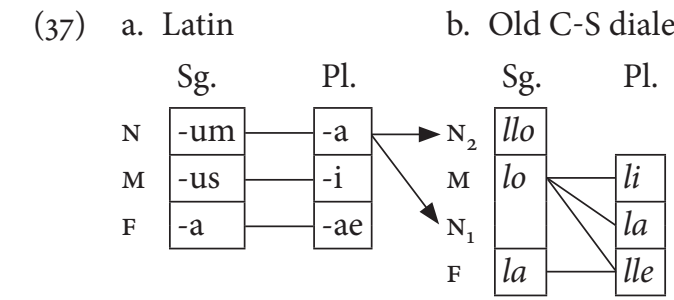

c. Modern C-S dialects

dialects

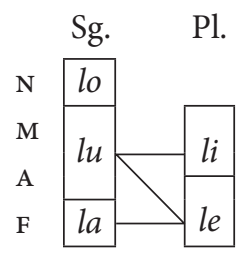

gender that can be labelled, at that stage, just as neuter ${ }_{1}$, to distinguish it from neuter ${ }_{2}{ }^{31}$ The neuter ${ }_{1}$, as we saw above (and as confirmed by the vacillation la/le with mura in (36)), was already in the process of becoming an alternating (controller) gender - hence the abbreviations ' $\mathrm{N}(>\mathrm{A})$ ' in (34)as its singular forms had long merged with the masculine. But the process did not reach completion until the feminine plural markers (ONeap lle $>$ MNeap $e$ ) became generalized eventually ousting la (< ILLA).

To sum up, the diachronic reconstruction put forward here can be schematized as in (37). The split of the Latin neuter, still reflected in Old Neapolitan, is shown in $(37 \mathrm{~b})$. At this stage, the system consists of four target genders, with masculine and feminine contrasting with a neuter ${ }_{1}$, which basically includes nouns that designate inanimate countables (largely, but not exclusively, with weakly individuated plurals, see (27)), contrasting with a neuter ${ }_{2}$, to which (singular) mass nouns are assigned. Neuter ${ }_{1}$ still has dedicated agreement forms in the plural, though the feminine ones can already be used as an alternative, as indicated by the association lines between singular and plural in (37b). Then, in a further step, the system in $(37 \mathrm{~b})$, with four distinct target genders, eventually simplified into the modern one (37c), with four controller genders, via the demise of the dedicated $a$-agreement forms in articles, determiners and adjectives.

\section{Conclusion}

Note that the evidence discussed in section 4 has been known to Romance scholars for a long time: yet, both the mass neuter and the plural $a$-agreement forms (like the article la and the demonstrative chesta) in (35) and

${ }^{31}$ Similar instances of plural verbal agreement co-occurring with neuter plural nominal inflection can be spotted also, although more sparingly, in other Romance branches, like Old French or Old Florentine (cf. Faraoni et al. to appear). 
(36) were usually lumped together into one and the same category 'remnants of the Latin neuter.' Of course, diachronically both indeed are. But synchronically, at this medieval stage we are facing two distinct agreement patterns, triggered by two complementary classes of lexemes/controllers. Which means, two distinct genders.

To conclude, then, there are some general lessons to be drawn from the development of the gender system in Central-Southern Italo-Romance. The first is that the overall morphological complexity of the nominal inflectional paradigms of the language may correlate negatively with the overall complexity of the gender-contrast system: in the final analysis, the reason why we have to recognize four distinct genders in the Italo-Romance dialects of the Centre-South is that their inflectional morphology is not so rich as to allow for a layered grouping of agreement markers in genders and subgenders of the kind displayed by the Slavic languages.

A second lesson is that, as odd as it may seem, given an inherited three-gender system, becoming four can be a transitory step along the way towards becoming two. In other words, despite appearances, the split of the (late) Latin neuter is a sign of instability that can be understood against the general background of the familiar drift towards reduction of gender categories in IE, seen above in (5).

Finally, the third lesson is that the change from target to controller gender - as seen in (37) - may also occur as an intermediate step on this path (as emphasized for IE languages by Igartua 2006: 58), since a controller gender, lacking dedicated agreement morphemes, is less salient. In our case, indeed, its salience was so limited that it was overlooked by legions of previous researchers for more than a century, since nobody, among the many who studied the dialects at issue, ever realized before that they provide robust evidence against the widely held opinion (see section 1) that four-gender systems are unattested in IE.

\section{Abbreviations}

$\begin{array}{llll}\text { A } & \text { alternating } & \text { DO } & \text { direct object } \\ \text { ABS } & \text { absolutive } & \text { F } & \text { feminine } \\ \text { ACC } & \text { accusative } & \text { IO } & \text { indirect object } \\ \text { C-S } & \text { Central-Southern } & \text { IMPF } & \text { imperfect } \\ \text { DEF } & \text { definite } & \text { LOC } & \text { locative }\end{array}$




$\begin{array}{llll}\text { M } & \text { masculine } & \text { PL } & \text { plural } \\ \text { MNeap } & \text { Modern Neapolitan } & \text { PRom } & \text { Proto-Romance } \\ \text { N } & \text { neuter } & \text { PRS } & \text { present } \\ \text { NOM } & \text { nominative } & \text { PRTV } & \text { partitive } \\ \text { OGr } & \text { Old Greek } & \text { PTP } & \text { past participle } \\ \text { OIA } & \text { Old Indo-Aryan } & \text { RF } & \text { Raddoppiamento } \\ \text { OInd } & \text { Old Indian } & & \text { Fonosintattico } \\ \text { ONeap } & \text { Old Neapolitan } & \text { SG } & \text { singular } \\ \text { (P)IE } & \text { (Proto-)Indo-European } & & \end{array}$

\section{References}

Acquaviva, Paolo. 2000. La grammatica italiana: il lavoro comincia adesso. Lingua e Stile 35: 249-271.

Acquaviva, Paolo. 2002. Il plurale in -a come derivazione lessicale. Lingue e Linguaggio 2: 295-326.

Acquaviva, Paolo. 2004. The morphosemantics of transnumeral nouns. In Geert Booij, Emiliano Guevara, Angela Ralli, Salvatore Sgroi \& Sergio Scalise, eds. Morphology and linguistic typology. On-line proceedings of the Fourth Mediterranean Morphology Meeting (MMM4), Catania, 21-23 Sept. 2003 [http://mmm. lingue.unibo.it/mmm-proc/MMM4].

Acquaviva, Paolo. 2008. Lexical plurals. Oxford: Oxford University Press.

Aebischer, Paul. 1933. Les pluriels analogiques en -ora dans les chartes latines de l'Italie. Archivum Latinitatis Medii Aevi 8: 55-76.

Aikhenvald, Alexandra. 2000. Classifiers: A typology of noun categorization devices. Oxford: Oxford University Press.

Aronoff, Mark. 1994. Morphology by itself. Cambridge, MA: MIT Press.

Avolio, Francesco. 1996. Il 'neutro di materia' nei dialetti centro-meridionali: fonti, dati recenti, problemi aperti. Contributi di Filologia dell' Italia Mediana 10: 291337.

Balles, Irene. 2004. Zur Rekonstruktion des früh-urindogermanischen Nominalklassensystems. In Adam Hyllested, Anders Richardt Jørgensen, Jenny Helena Larsson \& Thomas Olander, eds. Per aspera ad asteriscos. Studia indogermanica in honorem Jens Elmegård Rasmussen sexagenarii Idibus Martis anno MMIV. Innsbruck: Institut für Sprachwissenschaft der Universität, 43-57.

Bateman, Nicoleta \& Maria Polinsky. 2010. Romanian as a two-gender language. In Donna Gerdts, John Moore \& Maria Polinsky, eds. Festschrift for David Perlmutter. Cambridge, MA: MIT Press, 41-77.

Bejan, Dumitru. 20013. Gramatica limbii române. Compendiu. Cluj: Editura Echinox. 
Belardi, Walter. 1950. La questione del numero nominale. Ricerche Linguistiche 1: 204-233.

Berger, Hermann. 1998. Die Burushaski-Sprache von Hunza und Nager. Wiesbaden: Harassowitz.

Bloch, Jules. 1934. L'indo-aryen du Veda aux temps modernes. Paris: Adrien-Maisonneuve.

Bonfante, Giuliano. 1961. Esiste il neutro in italiano? Quaderni dell'istituto di glottologia dell'università di Bologna 6: 103-109 [also in Giuliano Bonfante, Studii Romeni. Rome: Società Accademica Romena 1973, 161-170].

Bonfante, Giuliano. 1964. Il neutro italiano, romeno, e albanese. Acta Philologica [Societas Academica Dacoromana] 3: 24-37 [also in Giuliano Bonfante, Studii Romeni. Rome: Società Accademica Romena 1973, 173-187].

Bonfante, Giuliano. 1977. Ancora il neutro italiano e romeno. L'Italia Dialettale 40: 287-292.

Breu, Walter. To appear. La ristrutturazione della categoria del genere grammaticale nello slavomolisano. In Dialetti: per parlare e parlarne, II Convegno Internazionale di Dialettologia (Progetto A. L. Ba.), Potenza - Venosa - Matera, 13-15 May 2010.

Brown, Dunstan. 1998. Defining 'subgender': Virile and devirilized nouns in Polish. Lingua 104: 187-233.

Brugmann, Karl. 1886-1900. Grundriss der vergleichenden Grammatik der indogermanischen Sprachen: Kurzgefasste Darstellung der Geschichte des Altindischen, Altiranischen, Altarmenischen, Altgriechischen, Albanesischen, Lateinischen, Oskisch-Umbrischen, Altirischen, Gotischen, Althochdeutschen, Litauischen und Altkirchenslavischen. Strassburg: s.n.

Campanile, Enrico. 1973. Sulla quantità della vocale che precede $-m$ in latino. L'Italia Dialettale 36: 1-6.

Clackson, James. 2007. Indo-European linguistics. Cambridge: Cambridge University Press.

Comrie, Bernard \& Greville G. Corbett. 1993. Introduction. In Bernard Comrie \& Greville G. Corbett, eds. The Slavonic languages. London \& New York: Routledge, 1-19.

Corbett, Greville G. 1982. Gender in Russian: An account of gender specification and its relationship to declension. Russian Linguistics 6: 197-232.

Corbett, Greville G. 1988. Gender in Slavonic from the standpoint of a general typology of gender systems. Slavonic and East European Review 66: 1-20.

Corbett, Greville G. 1991. Gender. Cambridge: Cambridge University Press.

Corbett, Greville G. 2005. Number of genders. In WALS 30: 126-127.

Corbett, Greville G. 2006. Agreement. Cambridge: Cambridge University Press.

Corbett, Greville G. \& Norman M. Fraser. 2000. Default genders. In Barbara Unterbeck, Matti Rissanen, Tertu Nevalainen \& Mirja Saari, eds. Genders in grammar and cognition. Berlin \& New York: Mouton de Gruyter, 55-97. 
D’Achille, Paolo \& Anna M. Thornton. 2003. La flessione del nome dall'italiano antico all'italiano contemporaneo. In Nicoletta Maraschio \& Teresa Poggi Salani, eds. Italia linguistica anno Mille, Italia linguistica anno Duemila (Atti del XXXIV Congresso internazionale di studi della Società di Linguistica Italiana, Firenze, 19-21 ottobre 2000). Rome: Bulzoni, 211-230.

De Blasi, Nicola. 2002. Per la storia contemporanea del dialetto nella città di Napoli. Lingua e Stile 37: 123-157.

De Blasi, Nicola. 2006. Profilo linguistico della Campania. Bari: Laterza.

De Blasi, Nicola \& Luigi Imperatore. 200o. Il napoletano parlato e scritto. Con note di grammatica storica (Nuova edizione). Naples: Dante \& Descartes.

Dixon, R. M.W. 2002. Australian languages: Their nature and development. Cambridge: Cambridge University Press.

Dressler, Wolfgang U. \& Lavinia Merlini Barbaresi. 1994. Morphopragmatics: Diminutives and intensifiers in Italian, German and other languages. Berlin \& New York: Mouton de Gruyter.

Dressler, Wolfgang U. \& Anna M. Thornton. 1996. Italian nominal inflection. Wiener Linguistische Gazette 57-59: 1-26.

Ebert, Karen. 1998. Genussynkretismus im Nordseeraum: Die Resistenz des Fering. In Winfried Boeder, Christoph Schroeder, Karl Heinz Wagner \& Wolfgang Wildgen, eds. Sprache in Raum und Zeit. In memoriam Johannes Bechert. Beiträge zur empirischen Sprachwissenschaft. Tübingen: Narr, 269-298.

Eichner, Heiner. 1985. Das Problem des Ansatzes eines urindogermanischen Numerus 'Kollektiv' ('Komprehensiv'). In Bernfried Schlerath \& Veronica Rittner, eds. Grammatische Kategorien, Funktion und Geschichte. Akten der VII. Fachtagung der Indogermanischen Gesellschaft, Berlin, 20.-25. Februar 1983. Reichert: Wiesbaden, 134-175.

Euler, Wolfram. 1991. Die Frage nach der Entstehung der indogermanischen Genera im Lichte der relativen Chronologie. Indogermanische Forschungen 96: $36-45$.

Evans, Nicholas, Dunstan Brown \& Greville G. Corbett. 2002. The semantics of gender in Mayali: Partially parallel systems and formal implementation. Language 78: 111-155.

Faraoni, Vincenzo, Francesco Gardani \& Michele Loporcaro. To appear. Manifestazioni del neutro nell'italo-romanzo medievale. Paper presented at the $26 e$ Congrés Internacional de Lingüística i Filologia Romàniques, València, 6-11 Sept. 2010.

Formentin, Vittorio. 1994. Dei continuatori del latino ille in antico napoletano. Studi Linguistici Italiani 20: 40-93, 196-233.

Formentin, Vittorio, ed. 1998. Loise de Rosa, Ricordi, 2 vols. Rome: Salerno.

Friedman, Jay. 1999. A lexical analysis of simple ${ }^{*}-r /-n$ heteroclisis in Proto-IndoEuropean. UCLA Indo-European Studies 1: 31-69. 
Fritz, Matthias. 1998. Die urindogermanischen s-Stämme und die Genese des dritten Genus. In Wolfgang Meid, ed. Sprache und Kultur der Indogermanen. $X$. Fachtagung der Indogermanischen Gesellschaft, Innsbruck, 22.-28. September 1996. Innsbruck: Institut für Sprachwissenschaft der Universität, 255-264.

Gardani, Francesco. 2009. Dynamics of morphological productivity. A synchronic analysis and diachronic explanation of the productivity of nominal inflection classes from archaic Latin to Old Italian in terms of natural morphology. Vienna: University of Vienna PhD Dissertation.

Graur, Alexander. 1928. Les substantifs neutres en roumain. Romania 26: 249-260.

Grune, Dick. 1998. Burushaski: An extraordinary language in the Karakoram mountains. Ms. Vrije Universiteit, Amsterdam [http://www.few.vu.nl/ dick/ Summaries/Languages/Burushaski.pdf.]

Haase, Martin. 200o. Reorganization of a gender system: The central Italian neuters. In Barbara Unterbeck, Matti Rissanen, Tertu Nevalainen \& Mirja Saari, eds. Genders in grammar and cognition. Berlin \& New York: Mouton de Gruyter, 221-236.

Hall, Robert. 1965. The 'neuter' in Romance: A pseudo-problem. Word 21: 421-427.

Hajnal, Ivo. 1994. Die lykischen $a$-Stämme: Zum Werdegang einer Nominalklasse. In Jens Elmegård Rasmussen \& Benedicte Nielsen, eds. In honorem Holger Pedersen. Kolloquium der Indogermanischen Gesellschaft vom 26. bis 28. März 1993 in Kopenhagen. Wiesbaden: Reichert, 135-171.

Hajnal, Ivo. 2004. Die lykischen $a$-Stämme. In Adam Hyllested, Anders Richardt Jørgensen, Jenny Helena Larsson \& Thomas Olander, eds. Per aspera ad asteriscos. Studia Indogermanica in honorem Jens Elmegård Rasmussen sexagenarii Idibus Martis anno MMIV. Innsbruck: Institut für Sprachwissenschaft der Universität, $187-205$.

Harðarson, Jón Axel. 1987. Zum urindogermanischen Kollektivum. Münchener Studien zur Sprachwissenschaft 48: 71-113.

Hockett, Charles F. 1958. A course in modern linguistics. New York: Macmillan.

Igartua, Iván. 2006. Genus alternans in Indo-European. Indogermanische Forschungen 111: 56-70.

Jakobson, Roman. 1971. On the Rumanian neuter. In Roman Jakobson, Selected writings. II. World and language. The Hague: Mouton, 187-189.

Kim, Ronald I. 2009. The feminine gender in Tocharian and Indo-European. In Brent Vine \& Kazuhiko Yoshida, eds. East and west: Papers in Indo-European studies, Bremen: Hempen, 69-87.

Krause, Wolfgang \& Werner Thomas. 1960. Tocharisches Elementarbuch. Vol. I: Grammatik. Heidelberg: Carl Winter.

Kuryłowicz, Jerzy. 1964. The inflectional categories of Indo-European. Heidelberg: Carl Winter Universitätsverlag. 
Lazzeroni, Romano. 1993. Il genere indoeuropeo. Una categoria naturale? In Maurizio Bettini, ed. Maschile/Femminile. Generi e ruoli nelle culture antiche, Bari: Laterza, 3-16. [also in Tristano Bolelli \& Saverio Sani, eds. Scritti scelti di Romano Lazzeroni. Pisa: Pacini 1997, 73-95].

Ledgeway, Adam. 2009. Grammatica diacronica del napoletano (Beihefte zur Zeitschrift für romanische Philologie, Band 350). Tübingen: Max Niemeyer Verlag.

Litscher, Roland. 2009. Die Genese des dritten Genus: ein neuer Versuch. In Rosemarie Lühr \& Sabine Ziegler, eds. Protolanguage and Prehistory. Akten der XII. Fachtagung der Indogermanischen Gesellschaft. Krakau, 11-15 Oct. 2004. Wiesbaden: Reichert, 271-285.

Loporcaro, Michele. 2009a. Dialetti. In Luigi Luca Cavalli Sforza, ed. La cultura italiana. Vol. 2: Lingue e linguaggi, ed. by Gian Luigi Beccaria. Turin: UTET, 126-205.

Loporcaro, Michele. 2009b. Sobre el origen del neutro asturiano: evidencia comparativa. Paper given at the 28th Xornaes Internacionales D'Estudiu de la Academia de la Llingua Asturiana, Uvieu/Oviedo, 3-5 Nov. 2009.

Lorenzetti, Luca. 1995. Aspetti morfologici e sintattici dei dialetti dei Castelli romani. Rome: University of Roma Tre PhD Dissertation.

Lorimer, David Lockhart Robertson. 1935. The Burushaski language. 3 vols. Oslo: Instituttet for Sammenlignende Kulturforskning.

Love, James Robert Beattie. 2000. The grammatical structure of the Worora language of North-Western Australia. München: Lincom Europa.

Lüdtke, Helmut. 1965. Die lateinischen Endungen -im, -um, -unt und ihre romanischen Ergebnisse. In Omagiu lui Alexandru Rosetti la 70 de ani. București: Editura Academiei Republicii Socialiste România, 487-499.

Maiden, Martin. 2011. Morphological persistence. In Martin Maiden, John Charles Smith \& Adam Ledgeway, eds. The Cambridge history of the Romance languages. Vol. I: Structures. Cambridge: Cambridge University Press, 155-215, 699-706.

Matasović, Ranko. 2004. Gender in Indo-European. Heidelberg: Winter.

Maturi, Pietro. 2002. Dialetti e substandardizzazione nel Sannio beneventano. Frankfurt a. M.: Peter Lang.

Mayrhofer, Manfred. 1996. Etymologisches Wörterbuch des Altindoarischen (EWAia). 2 vols. Heidelberg: C. Winter.

Meier-Brügger, Michael. 2002. Indogermanische Sprachwissenschaft. 8. Auflage, Berlin \& New York: de Gruyter.

Melchert, H. Craig. 1994. The feminine gender in Anatolian. In George E. Dunkel, Gisel Meyer, Salvatore Scarlata \& Christian Seidl, eds. Früh-, Mittel-, Spätindogermanisch. Akten der IX. Fachtagung der Indogermanischen Gesellschaft vom 5. bis 9. Oktober 1992 in Zürich. Wiesbaden: Reichert, 231-244. 
Melchert, H. Craig. 2011. The PIE collective plural and the 'tà zôa tréchei rule'. In Thomas Krisch \& Thomas Lindner, eds. Indogermanistik und Linguistik im Dialog. Akten der XIII. Fachtagung der Indogermanischen Gesellschaft vom 21. bis 27. September 2008 in Salzburg. Wiesbaden: Reichert, 395-400.

Meo, Domenico. 2003. Vocabolario del dialetto di Agnone. Agnone: s.n.

Merlo, Clemente. 1906-1907. Dei continuatori del lat. ille in alcuni dialetti dell' Italia centro-meridionale. Zeitschrift für romanische Philologie 30: 11-25, 438-454; 31: 157-163.

Merlo, Clemente. 1917a. L'articolo determinativo nel dialetto di Molfetta. Studj Romanzi 14: 69-99.

Merlo, Clemente. 1917b. Proposta di aggiunte ai $\$ \$ 336 / 352,383 / 384$ della 'Italienische Grammatik' di W. Meyer-Lübke. Studj Romanzi 14: 100-112.

Merlo, Clemente. 1952. Ital. 'Le Labbra, Le Braccia' e sim. Italica 29: 229-234.

Miranda, Rocky V. 1975. Indo-European gender: A study in semantic and syntactic change. Journal of Indo-European Studies 3: 199-215.

Neu, Erich. 1992. Zum Kollektivum im Hethitischen. In Onofrio Carruba, ed. Per una grammatica ittita. Pavia: Gianni Iuculano, 197-212.

Nolè, Graziella. 2004-2005. Ricerche sul dialetto di Avigliano. Vocalismo, consonantismo e morfologia nominale. Zurich: University of Zurich Graduation Thesis.

Ojeda, Almerindo E. 1995. The semantics of the Italian double plural. Journal of Semantics 12: 213-237.

Ostrowski, Manfred. 1985. Zur Entstehung und Entwicklung des indogermanischen Neutrums. In Bernfried Schlerath \& Veronica Rittner, eds. Grammatische Kategorien, Funktion und Geschichte. Akten der VII. Fachtagung der Indogermanischen Gesellschaft, Berlin, 20.-25. Februar 1983. Reichert: Wiesbaden, 313-323.

Paciaroni, Tania. 2009. Sulla flessione del nome in maceratese e sul suo sviluppo. Paper given at the XXXI Romanistentag, Bonn, 27 Sept-1 Oct. 2009.

Paciaroni, Tania, Graziella Nolè \& Michele Loporcaro. 2008. Sistemi a quattro generi in italoromanzo. Paper given at the workshop CIDSM [Cambridge Italian Dialect Syntax Meeting] in Italy. Pescara: Università G. D'Annunzio, 4-6 July 2008.

Pelaez, Mario. 1928. Un nuovo testo dei Bagni di Pozzuoli in volgare napoletano. Studj Romanzi 19: 47-134.

Pellegrini, Giovan Battista. 1977. Carta dei dialetti d'Italia. PDI o. Pisa: Pacini.

Pescarini, Diego. 2008. 'Ne Uter'. In Roberta Maschi, Nicoletta Penello \& Piera Rizzolatti, eds. Miscellanea di studi linguistici offerti a Laura Vanelli da amici e allievi padovani. Udine: Editrice Universitaria Udinese, 183-190. 
Pomino, Natascha \& Elisabeth Stark. 2007. Discreteness and the case of the Spanish 'neuter' demonstratives. In Georg A. Kaiser \& Manuel Leonetti, eds. Proceedings of the workshop Definiteness, Specificity and Animacy in Ibero-Romance Languages. Constanz: Universität Konstanz, 141-165.

Priestly, Tom M. S. 1983. On 'drift' in Indo-European gender system. Journal of Indo-European Studies 11: 339-363.

Rumsey, Alan. 1982. An intra-sentence grammar of Ungarinjin - North-Western Australia, Canberra: Department of Linguistics, Research school of Pacific Studies, The Australian National University (Pacific Linguistics, Series B, no. 86).

Schmidt, Claus-Peter. 1972. Maskuline Genuskongruenz beim Plural der Substantiva alternantia im Tocharischen. Frankfurt a. M: University of Frankfurt a. M Ph.D. Dissertation.

Schmidt, Johannes. 1889. Die Pluralbildungen der indogermanischen Neutra. Weimar: Hermann Böhlau.

Spitzer, Leo. 1941. Feminización del neutro (rumano oasele, italiano le ossa, ant. francés ces brace, español las vísceras). Revista de Filología Hispánica 3: 339-371.

Stang, Christian S. 1945. Zum indoeuropäischen Kollektivum. Norsk Tidsskrift for Sprogvidenskap 13: 282-294.

Stempel, Reinhard. 1994. $\bar{i}$-Genitiv, $\bar{\imath}$-Motion und Femininum: Versuch einer Synthese. In Roland Bielmeier \& Reinhard Stempel, eds. Indogermanica et Caucasica. Festschrift für K. H. Schmidt zum 65. Geburtstag. Berlin \& New York: Walter de Gruyter, 197-210.

ThLL: Thesaurus linguae Latinae: editus auctoritate et consilio academiarum quinque Germanicarum Berolinensis Gottingensis Lipsiensis Monacensis Vindobonensis. Leipzig: Teubner, 1900-.

Thornton, Anna. 2009. A non-canonical phenomenon in Italian verb morphology: double forms realizing the same cell ('overabundancy'). Lecture and handout from the workshop 'Irregularity in Morphology' (Festival der Sprachen), Bremen, 4-6 Oct. 2009.

Tichy, Eva. 1993. Kollektiva, Genus femininum und relative Chronologie im Indogermanischen. Historische Sprachwissenschaft 106: 1-19.

Turner, Robert L. 1966. A comparative dictionary of the Indo-Aryan languages. London: Oxford University Press.

Väänänen, Veikko. $1967^{2}$. Introduction au latin vulgaire. Paris: Klincksieck.

WALS: Martin Haspelmath, Matthew S. Dryer, David Gil \& Bernard Comrie, eds. 2005. The world atlas of language structures. Oxford: Oxford University Press.

Zaliznjak, Andrej A. 1964. K voprosu o grammatičeskix kategorijax roda i oduševlennosti v sovremennom russkom jazyke [On the issue of the grammatical categories gender and animacy in contemporary Russian]. Voprosy jazykoznanija 4: $25-40$. 
Zeilfelder, Susanne. 2001. Archaismus und Ausgliederung: Studien zur sprachlichen Stellung des Hethitischen. Heidelberg: Carl Winter.

Ziccardi, Giovanni. 1910. Il dialetto di Agnone. La fonetica e la flessione. Zeitschrift für romanische Philologie 34: 405-436.

\author{
Authors' address \\ Universität Zürich \\ Romanisches Seminar \\ Zürichbergstrasse 8 \\ CH-8032 Zürich, Switzerland \\ E-mail: loporcar@rom.uzh.ch, \\ paciaron@rom.uzh.ch
}




\title{
NEW HANDBOOK SERIES: THE WORLD OF LINGUISTICS
}

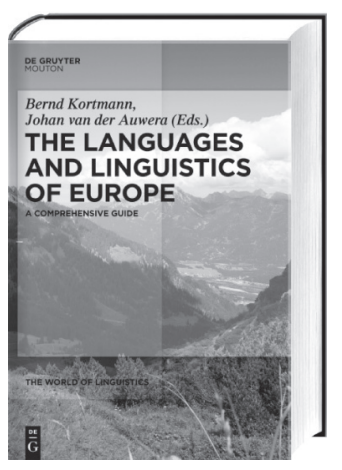

Volume 1

\section{THE LANGUAGES AND LINGUISTICS OF EUROPE}

\author{
A Comprehensive Guide
}

Ed. by Bernd Kortmann, Johan van der Auwera 2011. xviii, $911 \mathrm{pp}$.

Hc. RRP $€ 249.95 / *$ US $\$ 375.00$. Standing Order price for subscribers to the complete work $€ 199.95 / *$ US $\$ 300.00$ ISBN 978-3-11-022025-4

eBook RRP € 249.95/*US\$ 375.00. ISBN 978-3-11-022026-1

Print + eBook RRP € 369.00/*US\$554.00

ISBN 978-3-11-173475-0

The book supplies profiles of the language families of Europe, including the sign languages. Separate chapters deal with the old and new minority languages and with non-standard varieties. A major focus is language politics and policies, including discussions of the special status of English, the relation between language and the church, language and the school, and standardization. The history of European linguistics is another focus as is the history of multilingual European 'empires' and their dissolution.

Volume 2

\section{THE INDIGENOUS LANGUAGES OF SOUTH AMERICA}

\author{
A Comprehensive Guide \\ Ed. by Lyle Campbell, Verónica Grondona \\ 2011. Approx. $x x, 700$ pp. \\ Hc. RRP € $249.95 / *$ US $\$ 375.00$
}

Standing Order price for subscribers to the complete work $€ 199.95$ /*US $\$ 300.00$

ISBN 978-3-11-025513-3

eBook RRP $€ 249.95$ /*US\$ 375.00. ISBN 978-3-11-025803-5

Print + eBook RRP € 369.00/*US\$554.00. ISBN 978-3-11-220414-6

With more than a third of the linguistic diversity of the world, South American languages contribute new findings in most areas of linguistics. The extensive descriptive and historical linguistic research in recent years is represented in this volume in in-depth treatments, with chapters on the history of investigation, language classification, language endangerment, language contact, typology, phonology and phonetics, and on major language families and regions of South America.

\section{DE DE GRUYTER MOUTON}

*for orders placed in North America. Prices do not include postage and handling. Prices are subject to change. 